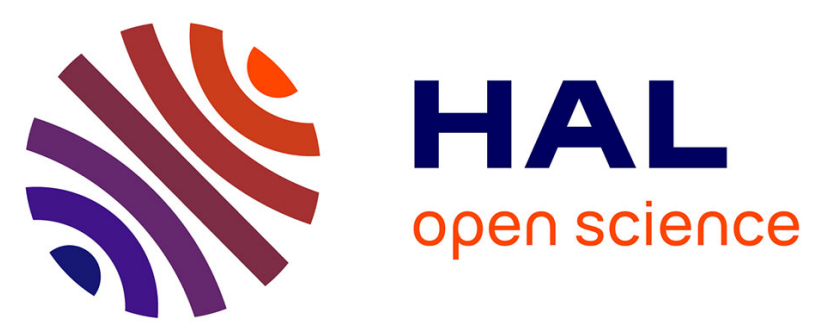

\title{
Exploiting the Reactivity of Fluorinated 2-Arylpyridines in Pd-Catalyzed C-H Bond Arylation for the Preparation of Bright Emitting Iridium(III) Complexes
}

Rabab Boyaala, Marie Peng, Wun-Shan Tai, Rachid Touzani, Thierry Roisnel, Vincent Dorcet, Yun Chi, Véronique Guerchais, Henri Doucet, Jean-François Soulé

\section{To cite this version:}

Rabab Boyaala, Marie Peng, Wun-Shan Tai, Rachid Touzani, Thierry Roisnel, et al.. Exploiting the Reactivity of Fluorinated 2-Arylpyridines in Pd-Catalyzed C-H Bond Arylation for the Preparation of Bright Emitting Iridium(III) Complexes. Inorganic Chemistry, 2020, 59 (19), pp.13898-13911. 10.1021/acs.inorgchem.0c01528 . hal-03040129

\section{HAL Id: hal-03040129 https://hal.science/hal-03040129}

Submitted on 4 Dec 2020

HAL is a multi-disciplinary open access archive for the deposit and dissemination of scientific research documents, whether they are published or not. The documents may come from teaching and research institutions in France or abroad, or from public or private research centers.
L'archive ouverte pluridisciplinaire HAL, est destinée au dépôt et à la diffusion de documents scientifiques de niveau recherche, publiés ou non, émanant des établissements d'enseignement et de recherche français ou étrangers, des laboratoires publics ou privés. 


\section{Exploiting the Reactivity of Fluorinated 2-Arylpyridines in Pd- Catalyzed C-H Bond Arylation for the Preparation of Bright Emitting Iridium(III) Complexes}

Rabab Boyaala, $\uparrow, \ddagger$ Marie Peng, $\dagger$ Wun-Shan Tai,II $\S$ Rachid Touzani, $\neq$ Thierry Roisnel, $\dagger$ Vincent Dorcet, $†$ Yun Chi, II $\S *$ Véronique Guerchais, $\dagger^{*}$ Henri Doucet, $\dagger^{*}$ and Jean-François Soulét*

$†$ Univ Rennes, CNRS UMR6226, F-3500 Rennes, France.

\$ Laboratoire de Chimie Appliquée et Environnement (LCAE), Faculté des Sciences, Université Mohamed Premier, Oujda, Morocco.

II Department of Chemistry, National Tsing Hua University, Hsinchu 30013, Taiwan;

$\S$ Department of Materials Science and Engineering, City University of Hong Kong, Hong Kong SAR

KEYWORDS. Catalysis - Palladium - C-H Bond Functionalization - Iridium Luminescence.

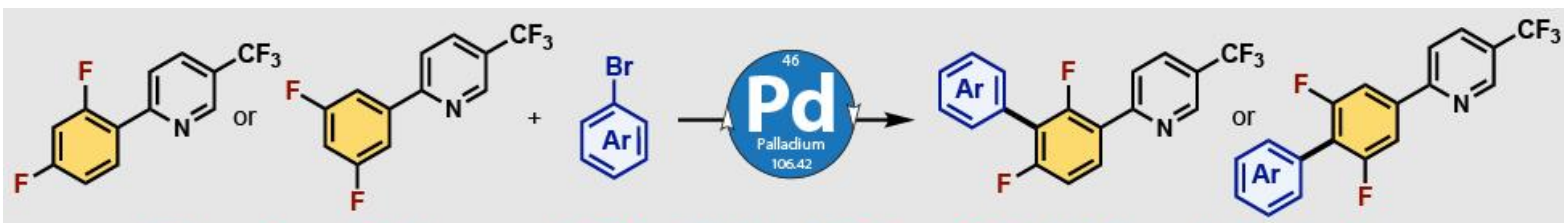

Fluorine Enhanced Site Selectivity of C-H Bond Arylation
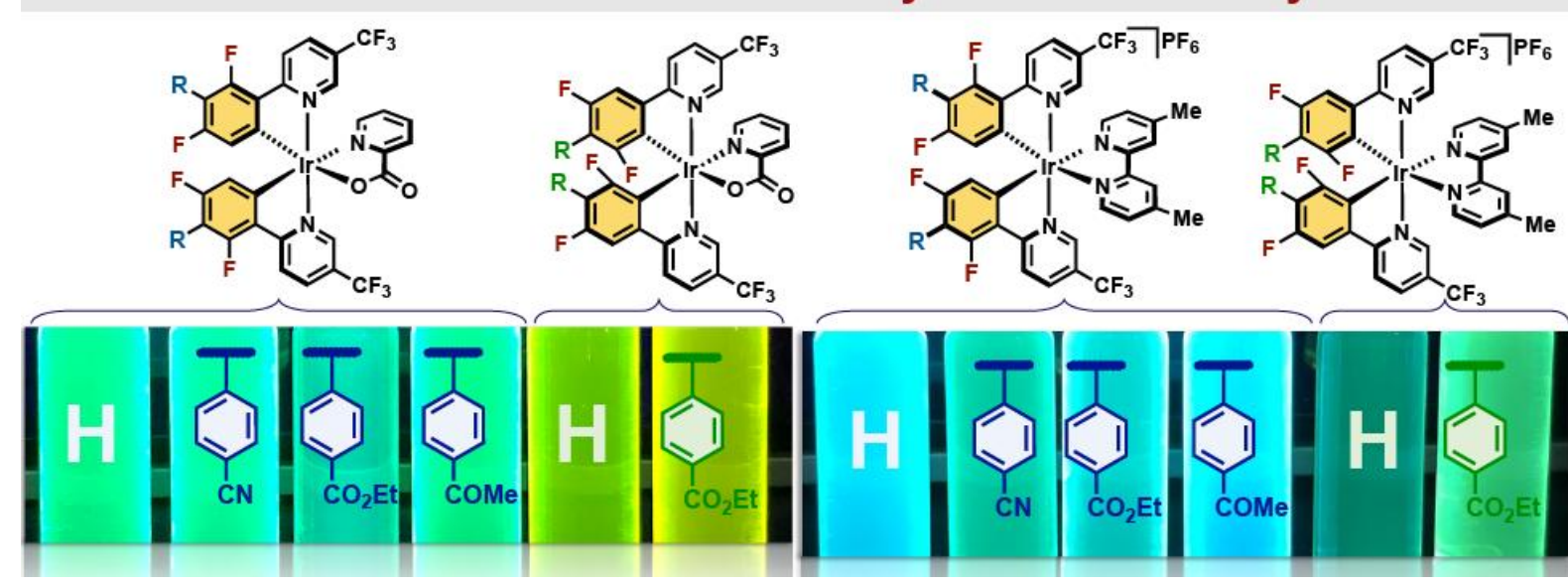

ABSTRACT. Pd-catalyzed C-H bond arylation applied to 2-(2,4-difluorophenyl)-5(trifluoromethyl)pyridine

(1) and 2-(3,5-difluorophenyl)-5-(trifluoromethyl)pyridine allows the access to two families of $\operatorname{Ir}(\mathrm{III})$ complexes, charge-neutral and cationic species. 
The reaction is regioselective since only the C3- or C4-position of the fluorinated phenyl ring of $\mathbf{1}$ or $\mathbf{5}$ is readily functionalized - namely the $\mathrm{C}-\mathrm{H}$ bond flanked by the two fluorine atoms which is the most acidic - which allows the electronic control of the reactive site. A range of electron-withdrawing $\left(\mathrm{CN}, \mathrm{CO}_{2} \mathrm{Et}, \mathrm{C}(\mathrm{O}) \mathrm{Me}\right)$ substituents on the aryl group has been incorporated leading to the pro-ligands (Ar-2,4-dFppy; 2, $\mathrm{Ar}=p-\mathrm{C}_{6} \mathrm{H}_{4}-\mathrm{CN} ; \mathbf{3}, \mathrm{Ar}=p-\mathrm{C}_{6} \mathrm{H}_{4}$ $\mathrm{CO}_{2} \mathrm{Et} ; 4$, $\mathrm{Ar}=p-\mathrm{C}_{6} \mathrm{H}_{4}-\mathrm{C}(\mathrm{O}) \mathrm{Me} ;$ and Ar-3,5-dFppy; 6, $\left.\mathrm{Ar}=p-\mathrm{C}_{6} \mathrm{H}_{4}-\mathrm{CO}_{2} \mathrm{Et}\right)$. The unsubstituted complexes F/G-1 and F/G-5 featuring $\mathbf{1}$ and $\mathbf{5}$ respectively, as $\mathrm{C}^{\wedge} \mathrm{N}$ ligands are used as reference complexes. The families of five charge-neutral $\left[\operatorname{Ir}\left(\mathrm{C}^{\wedge} \mathrm{N}\right)_{2}\left(\mathrm{~N}^{\wedge} \mathrm{O}\right)\right]$ complexes $\left(\mathrm{C}^{\wedge} \mathrm{N}\right.$ is 2-(5-aryl-(4,6-difluorophenyl)-5-(trifluoromethyl)pyridinato (F2-F4), and 2-(4-aryl(3,5-difluorophenyl)-5-(trifluoromethyl)pyridinato (F5-F6), $\mathrm{N}^{\wedge} \mathrm{O}=2$-picolinate] and five cationic $\left[\operatorname{Ir}\left(\mathrm{C}^{\wedge} \mathrm{N}\right)_{2}\left(\mathrm{~N}^{\wedge} \mathrm{N}\right)\right] \mathrm{PF}_{6}$ complexes $\left[\mathrm{N}^{\wedge} \mathrm{N}=\right.$ dmbpy is 4,4'-dimethyl-2,2'-bipyridine] (G2-G6) were synthesized and their structural and photophysical properties studied with comparison to the unsubstituted analogues used as reference complexes. The appended aryl group provides large steric bulk as the biaryl fragment is twisted as shown by the X-ray crystal structures of F2, F5, F6, G3 and G5. These latter complexes display a wide variety of different Ir...Ir intermetallic distances in crystals, from $8.150 \AA$ up to $15.034 \AA$. Moreover, the impact on the emission energy is negligible, as a result of the breaking of the conjugation between the two aryl groups. Charge-neutral complexes $\left[\operatorname{Ir}\left(\mathrm{C}^{\wedge} \mathrm{N}\right)_{2}\left(\mathrm{~N}^{\wedge} \mathrm{O}\right)\right]\left(\mathrm{N}^{\wedge} \mathrm{O}=2\right.$ picolinate) show bright luminescence: F2-F4 $\left(\lambda_{\mathrm{em}}=495-499 \mathrm{~nm}\right)$ are blue-green emitters whereas F5 and F6 $\left(\lambda_{\mathrm{em}}=537,544 \mathrm{~nm}\right)$, where the fluorine substituents are located at the C3- and C5-positions, emit in the green region of the visible spectrum. In all cases, a unitary photoluminescence quantum yield is found. The improvement of $\phi$ might be explained by an increase of the radiative rate constant due to a higher degree of rigidity of these congested molecules, compared to the unsubstituted complex F1. The same trends are observed for the family of complexes G. Complexes G1-G4 exhibit blue photoluminescence, and G5 and G6 leads to a red-shifted emission band, as also found for the related complexes F5 and F6 due to the similar fluorine substitution pattern. Their emission quantum yields are remarkably high for charged complexes in $\mathrm{CH}_{2} \mathrm{Cl}_{2}$ solution. These results showed that $\mathrm{Pd}$-catalyzed $\mathrm{C}-\mathrm{H}$ bond arylation is a valuable synthetic approach for designing efficient emitters with tunable photophysical properties.

\section{INTRODUCTION}


The design and synthesis of cyclometalated iridium(III) complexes has focused much interest for their applications in electroluminescent devices due to their intriguing luminescent behavior, i.e., long-lived excited states, high luminescence efficiencies, and facile color's tuning by ligand design. ${ }^{1}$ Typically, bis-cyclometalated ppy-based (ppyH 2phenylpyridine) neutral $\operatorname{Ir}(\mathrm{III})$ complexes of the type $\left[\operatorname{Ir}\left(\mathrm{C}^{\wedge} \mathrm{N}\right)_{2}\left(\mathrm{~L}^{\wedge} \mathrm{X}\right)\right]\left(\right.$ where $\mathrm{C}^{\wedge} \mathrm{N}$ and $\mathrm{L}^{\wedge} \mathrm{X}$ are cyclometalated ligand and monoanionic ancillary) were employed as dopants in organic light-emitting diodes (OLEDs), ${ }^{2}$ while their cationic congeners $\left[\operatorname{Ir}\left(\mathrm{N}^{\wedge} \mathrm{C}\right)_{2}\left(\mathrm{~N}^{\wedge} \mathrm{N}\right)\right] \mathrm{PF}_{6}\left(\mathrm{~N}^{\wedge} \mathrm{N}\right.$ is a di-imine ligand) were used in light-emitting electrochemical cells (LEECs). ${ }^{3}$

A plethora of charge-neutral and cationic phosphorescent Ir-ppy based complexes displaying emission ranging from red to blue have been reported to date, their synthesis and photophysical properties being well-documented in the literature. ${ }^{4}$ Numerous chemical modifications allowing the control of the emission energy have been reported. For instance, in the case of the neutral iridium(III)bis[(4,6-difluorophenyl)-pyridinato- $\left.N, C 2^{\prime}\right]$ picolinate FIrpic, A (Figure 1), the most studied bis-cyclometalated iridium complex, ${ }^{5}$ introduction of strong electron-withdrawing substituents such as perfluorocarbonyl, ${ }^{6}$ benzoyl $^{7}$ or diphenylphosphoryl $^{8}$ groups (Figure 1, complexes B-D) onto the phenyl ring at the C5position allows to further blue-shift the emission, whereas $\mathrm{CF}_{3}-$ Firpic ${ }^{9}$ (F1, Figure 1) derivative incorporating an electron-withdrawing substituent at the 5-position of the pyridine ring of dF-ppy displays a bathochromic shift of the emission when compared to the parent unsubstituted complex.

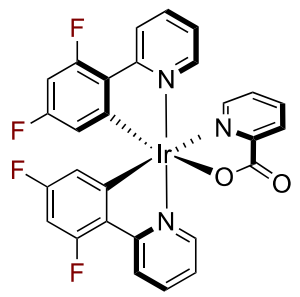

FIrpic (A)

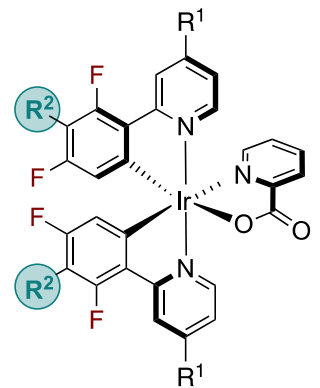

B: $\mathrm{R}^{1}=\mathrm{Me}, \mathrm{R}^{2}=\mathrm{COCF}_{3}$

C: $R^{1}=H, R^{2}=C O P h$

D: $R^{1}=H, R^{2}=\mathrm{POPh}_{2}$
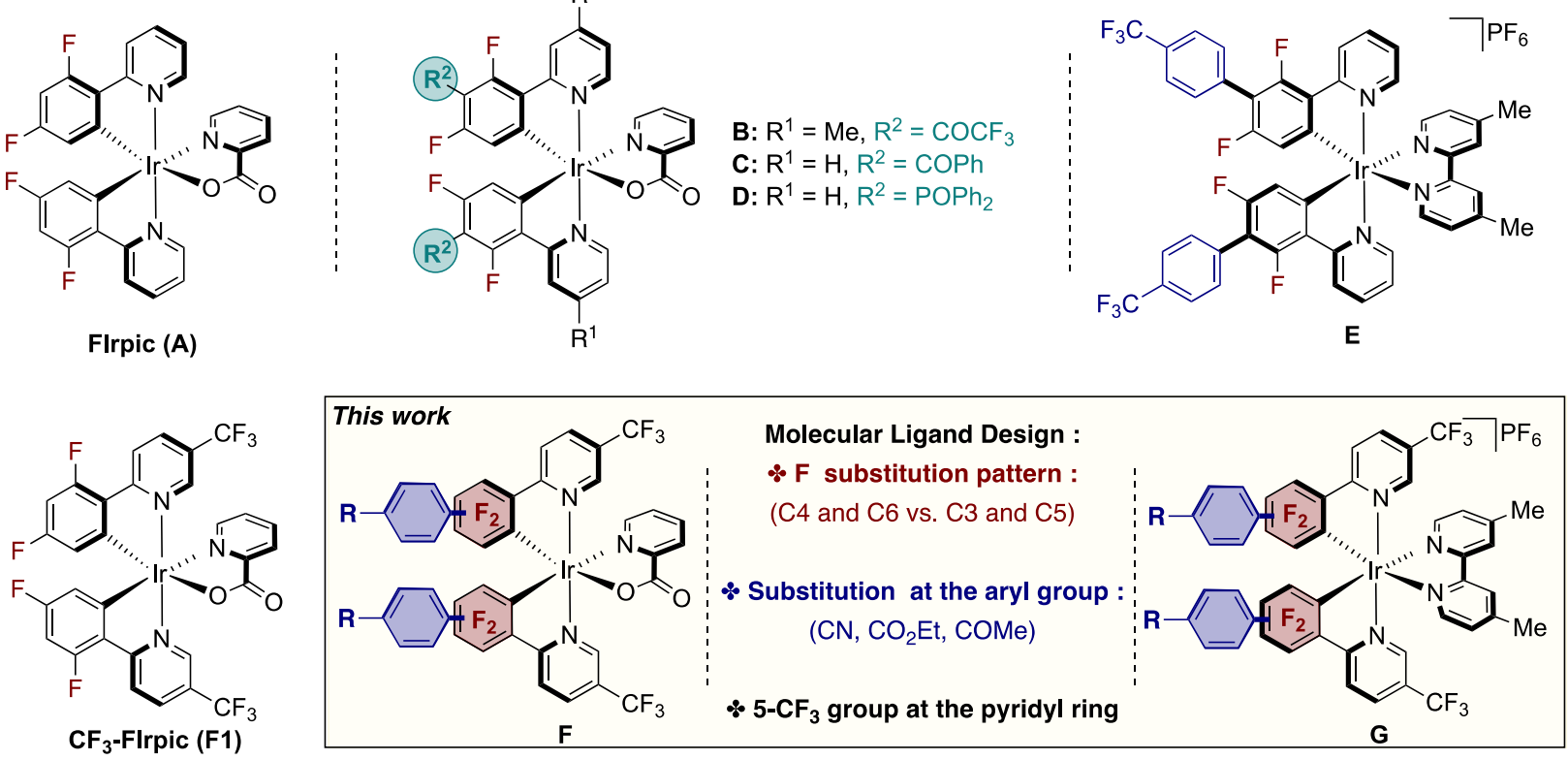
Figure 1. Selected Examples of Cyclometalated Iridium Complexes with difluorinated 2arylpyridine as $\mathrm{C}^{\wedge} \mathrm{N}$ Ligand and Structure of the Investigated Charge-Neutral and Cationic Iridium Complexes

Adding electron-withdrawing or-donating substituents on the $\mathrm{C}^{\wedge} \mathrm{N}$ ligand is a traditional way to modify the electronic structure of resulting complexes, and hence the color of the emission. On the contrary, the emission energy is not subject to change when adding sterically bulky aryl substituents at the 4-position of the pyridine ring of the $\mathrm{C}^{\wedge} \mathrm{N}$-ppy ligand, the attainment of a coplanar conformation between the two aromatics is inhibited leading to a disruption of the conjugation. ${ }^{3 \mathrm{~h}, 10}$ This ligand design has been applied for both charge-neutral and cationic bis-cyclometalated complexes, and the decrease of the intermolecular interactions, due to steric hindrance, has led to the most successful complexes with improved device performances. In a synthetic point of view, it is worth-mentioning that in all cases, aryl-appended pro-ligands of $\mathrm{dFppyH}$, were prepared, prior to metal complexation, using classical Suzuki carbon-carbon cross-coupling reactions. To facilitate the access to a large variety of complexes with tunable photophysical properties, we have developed the late-stage modification of fluorinated 2-arylpyridines and 2-arylquinolines, which allowed us to build a library of nitrogen-based pro-ligands in only one-step. ${ }^{11}$ Our approach was based on regiodivergent metal-catalyzed $\mathrm{C}-\mathrm{H}$ bond arylations. We showed that in the presence of palladium catalysts, the $\mathrm{C}-\mathrm{H}$ bond arylation occurred at the adjacent position of the fluorine atoms while using a ruthenium catalyst, the ortho- $\mathrm{C}-\mathrm{H}$ bond of the pyridine or quinoline rings is the selective site of functionalization. Moreover, the corresponding cationic iridium(III) complexes $\left[\operatorname{Ir}\left(\mathrm{C}^{\wedge} \mathrm{N}\right)_{2}\left(\mathrm{~N}^{\wedge} \mathrm{N}\right)\right] \mathrm{PF}_{6}$ featuring these synthesized $p-\mathrm{CF}_{3}-\mathrm{C}_{6} \mathrm{H}_{4}-$ appended $\mathrm{C}^{\wedge} \mathrm{N}$-ligands (see for instance, complex E, Figure 1) display an increased photoluminescence quantum yield, compared to the unsubstituted complex. ${ }^{11}$ Interestingly, the emission band is not affected by this chemical modification, as already observed for the related series of iridium(III) complexes where the substitution is achieved at the 4-position of the pyridyl ring. ${ }^{10,12}$ The color of the emission depends on the $\mathrm{C}^{\wedge} \mathrm{N}$ ligand, i.e., the position and number of the fluorine atoms as well as the nature of the nitrogen-based (pyridine or quinoline) ligand. Complex $\mathbf{E}$ displays a bright luminescence in the green region $\left(\lambda_{\mathrm{em}}=525\right.$ $\mathrm{nm}$ ) of the visible spectrum. The nature of the substituent of the incorporated aryl group on the photophysical properties was not investigated at this time, as well as the substitution on the pyridine ring. Only, the para-trifluoromethyl-substituted bromo derivative $p-\mathrm{CF}_{3}-\mathrm{C}_{6} \mathrm{H}_{4} \mathrm{Br}$ was used as the reagent, the first catalytic step of oxidative addition being facilitated, in order 
to establish the best catalytic conditions for both $\mathrm{Pd}$ and $\mathrm{Ru}$ catalytic systems. In order to further explore the scope of this reaction, we decided to investigate $\mathrm{Pd}$-catalyzed $\mathrm{C}-\mathrm{H}$ bond arylation $^{13}$ of $\mathrm{dF}_{-} \mathrm{CF}_{3}$ ppy derivatives using various bromoaryl reagents. Fluorobenzene derivatives are generally very reactive substrates in $\mathrm{Pd}$-catalyzed $\mathrm{C}-\mathrm{H}$ bond arylation, ${ }^{14}$ because fluorine atoms often enhance the reactivity of the adjacent $\mathrm{C}-\mathrm{H}$ bonds owing to their electronic properties, leading in most cases to site selective reactions. ${ }^{15}$ However, 2(difluorophenyl)-5-(trifluoromethyl)pyridine $\left(\mathrm{dF}_{-} \mathrm{CF}_{3} \mathrm{ppyH}\right)$ derivatives are more challenging substrates in terms of regioselectivity as the presence of the electron-withdrawing 5trifluoromethyl substituent on the pyridine ring could also enhance the reactivity of the adjacent $\mathrm{C}-\mathrm{H}$ bond, ${ }^{16}$ which could lead to side reactions.

In this report, we extend our catalytic approach to prepare two families of $\operatorname{Ir}(\mathrm{III})$ complexes, neutral $\left(\mathbf{F}^{9}\right)$ and cationic species $\left(\mathbf{G}^{17}\right)$ (see Figure 1) containing new aromatically substituted $\mathrm{C}^{\wedge} \mathrm{N}$ ligands based on 2-(2,4-difluorophenyl)-5-(trifluoromethyl)pyridine (1) and 2-(3,5-difluorophenyl)-5-(trifluoromethyl)pyridine (5) (Scheme 1), by using regioselective Pd-catalyzed $\mathrm{C}-\mathrm{H}$ bond arylations. Various aryl groups substituted at the para-position by an electron-withdrawing group $\left(\mathrm{CN}, \mathrm{CO}_{2} \mathrm{Et}, \mathrm{C}(\mathrm{O}) \mathrm{Me}\right)$ are readily incorporated, the regioselectivity being electronically controlled by the two fluorine atoms of pro-ligands $\mathbf{1}$ and 5.

Herein, we report the synthesis, the X-ray crystal structures, and the solution-state photophysical properties of $(i)$ a family of 2-picolinato complexes of the form [ $\operatorname{Ir}(\mathrm{Ar}-\mathrm{dF}-$ $\mathrm{CF}_{3}$ ppy) $)_{2}$ (pic)] $\mathbf{F}$ and (ii) a series of positively-charged complexes [Ir(Ar-dF$\mathrm{CF}_{3}$ ppy $)_{2}(\mathrm{dmbpy}) \mathrm{PF}_{6} \mathbf{G}$ having a 4,4'dimethyl-2,2'-bipyridine ancillary. This will allow us to evaluate the role of the added aryl substituent at the cyclometalated difluorinated phenyl ring of the $\mathrm{C}^{\wedge} \mathrm{N}$ ligand on the photophysical properties by comparison with the unsubstituted analogues (F1 ${ }^{9}$ /F5 and G1/G5, Schemes 2 and 3) used as reference complexes. ${ }^{14}$ We also show that the color of the emission can be fine-tuned by changing the position of the fluorine atoms in both series of complexes (F1-4 vs. F5-6 and G1-4 vs. G5-6, see Schemes 2 and 3), from blue to blue-green.

\section{RESULT AND DISCUSSION}

Synthesis. Firstly, we studied the reactivity of 2-(2,4-difluorophenyl)-5(trifluoromethyl)pyridine (1) in palladium-catalyzed $\mathrm{C}-\mathrm{H}$ bond arylation with 4bromobenzonitrile as the aryl source (Scheme 1). Using our previous optimized reaction 
conditions, namely $5 \mathrm{~mol} \%$ of $\mathrm{PdCl}\left(\mathrm{C}_{3} \mathrm{H}_{5}\right)(\mathrm{dppb})$ [dppb = 1,4-bis(diphenylphosphino)butane] associated with 2 equivalents of PivOK as base in DMA at $150{ }^{\circ} \mathrm{C}$, the $\mathrm{C}-\mathrm{H}$ bond arylation took place regioselectivity on the aryl ring at the most acidic $\mathrm{C}-\mathrm{H}$ bond, i.e. the one flanked by two fluorine atoms, affording the arylated proligand 2 in $64 \%$ yield. Other pro-ligands 3 and 4 were prepared using the same procedure from ethyl 4-bromobenzoate and 4bromoacetophenone in $68 \%$ and $61 \%$ yield, respectively. We have also investigated the reactivity of 2-(3,5-difluorophenyl)-5-(trifluoromethyl)pyridine (5) using ethyl 4bromobenzoate as coupling partner. Again, the $\mathrm{C}-\mathrm{H}$ bond arylation under palladium catalysis occurred at the most acidic position to give $\mathbf{6}$ in $72 \%$ as single regioisomer. As we previously observed in the case of 2-(2,4-difluorophenyl)pyridine, ${ }^{11}$ these phosphine-free palladium conditions are sensitive to the electronic nature of the aryl bromide as only electron-deficient aryl bromides were efficiently coupled owing to their faster rates of the oxidative addition to palladium. However, in all cases, the reaction was very regioselective, affording only the direct arylation at the $\mathrm{C}-\mathrm{H}$ bond flanked by the two fluorine atoms. These results show that the presence of the $5-\mathrm{CF}_{3}$ group on the pyridine ring does not perturb the site selectivity of the catalytic reaction.
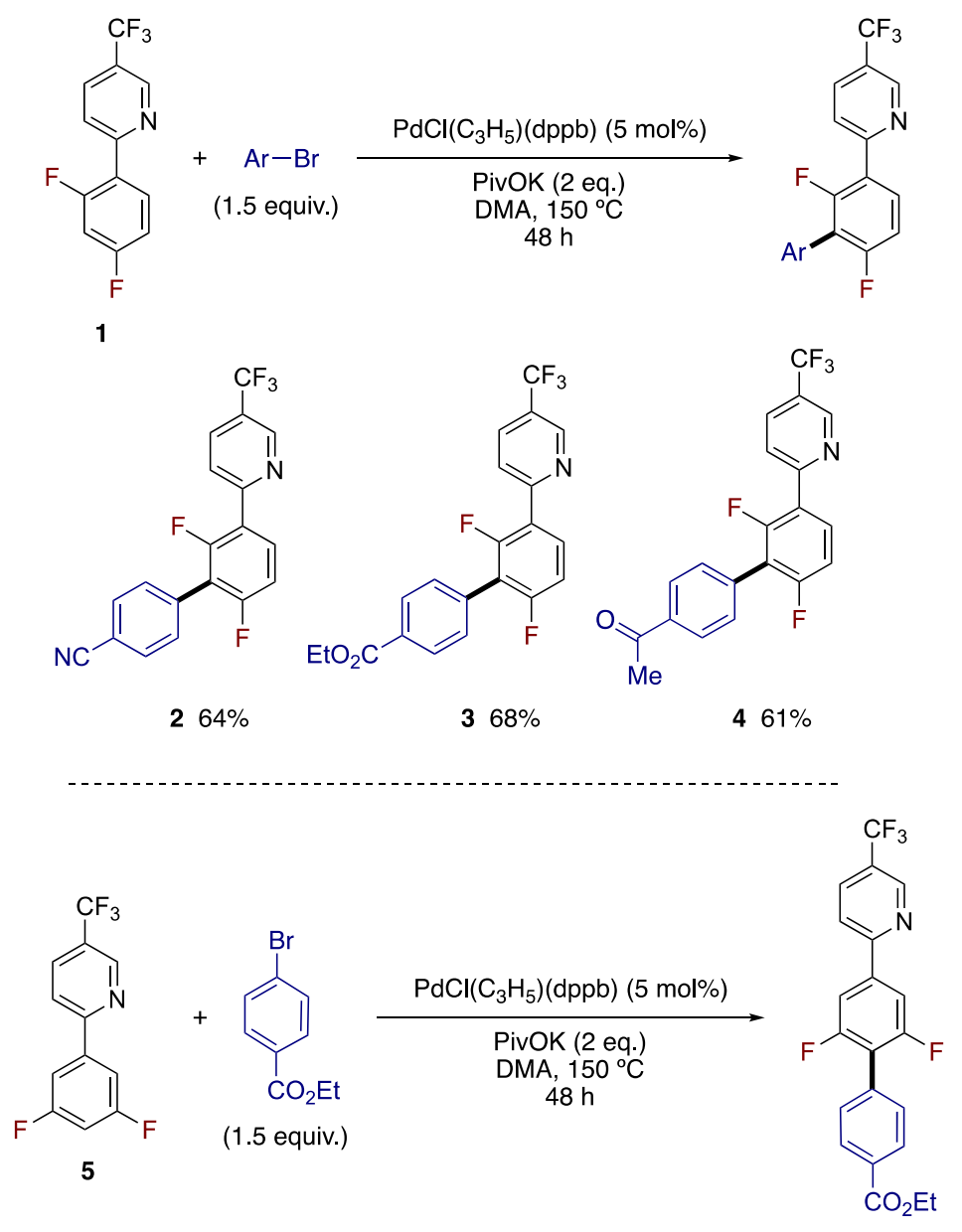
Scheme 1. Pd-Catalyzed C-H Bond Arylation of 2-(2,4-Difluorophenyl)-5(trifluoromethyl)pyridine (1) and 2-(3,5-Difluorophenyl)-5-(trifluoromethyl)pyridine (5)

Having synthesized the new pro-ligands 1-6 in pure form via $\mathrm{Pd}$-catalyzed $\mathrm{C}-\mathrm{H}$ bond arylation, we turned our attention to the preparation of charge-neutral iridium(III) complexes F, $\mathrm{CF}_{3}$-FIrpic congeners of F1 (Scheme 2). The cyclometalated iridium $\mu$-chloro-bridged dimers $\left[\left(\mathrm{C}^{\wedge} \mathrm{N}\right)_{2} \operatorname{Ir}(\mu-\mathrm{Cl})\right]_{2}$ were prepared using a classical procedure which consists of a treatment of $\mathrm{IrCl}_{3} \cdot 3 \mathrm{H}_{2} \mathrm{O}$ with 1-6 in a mixture of 2-ethoxyethanol and water at $125{ }^{\circ} \mathrm{C}$ for 24h. Then, the crude dimer was treated, without any purification, with 2-picolinic acid in the presence of sodium carbonate in 2-ethoxyethanol at $125^{\circ} \mathrm{C}$ over $24 \mathrm{~h}$ to afford the nonarylated reference complexes $\mathbf{F} \mathbf{1}^{9}$ and $\mathbf{F 5}$ bearing a different difluoro phenyl substituted $(4,6-$ difluorophenyl and 3,5-difluorophenyl, respectively) cyclometalated ligand and the corresponding arylated complexes F2, F3, F4 and F6 featuring a biaryl unit. The novel complexes F2-F6 were characterized by ${ }^{1} \mathrm{H}-\mathrm{NMR},{ }^{13} \mathrm{C}-\mathrm{NMR}$, and ${ }^{19} \mathrm{~F}-\mathrm{NMR}$ spectroscopy and high-resolution mass spectrometry (HRMS) (Synthesis details in SI).

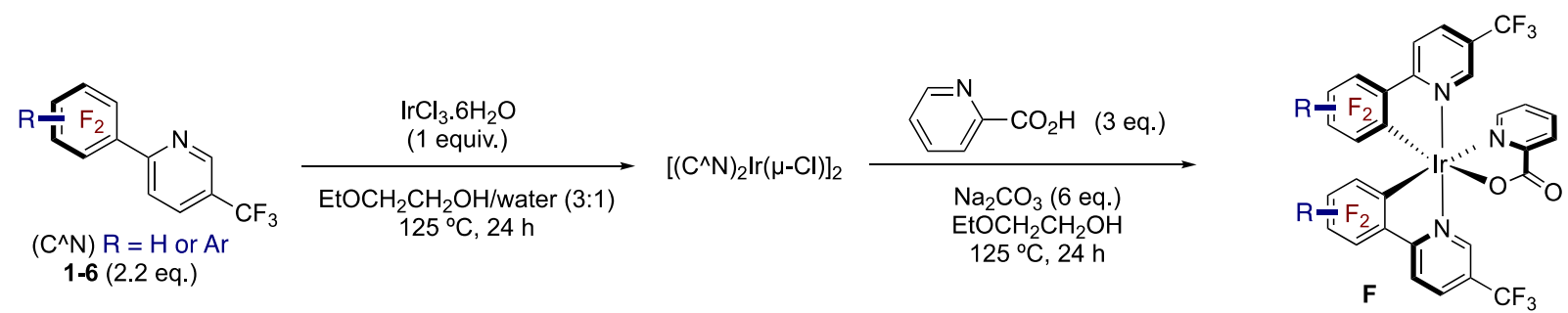

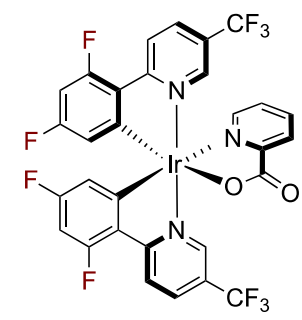

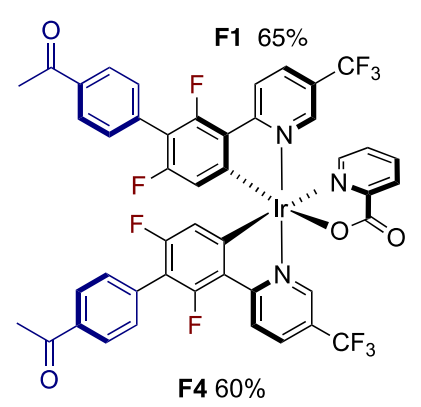

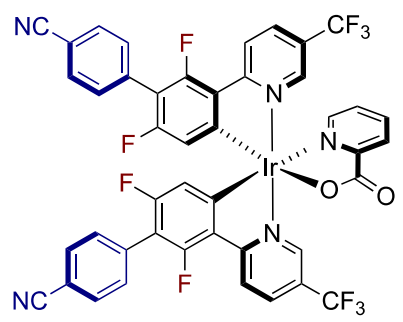

F2 68\%

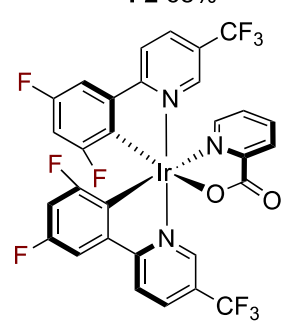

F5 $68 \%$

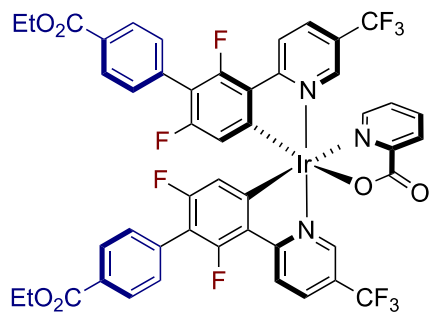

F3 62\%

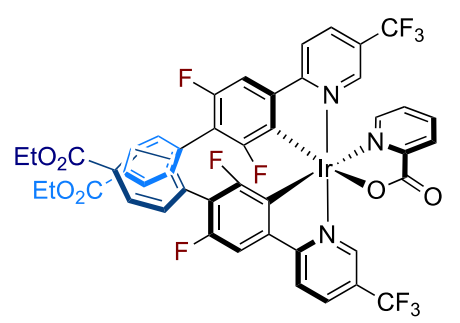

F6 $66 \%$

Scheme 2. Preparation of Complexes F1-F6 with Pyridine-2-carboxylate as Ancillary Ligand 
The second family of cationic iridium complexes $\left[\operatorname{Ir}\left(\mathrm{C}^{\wedge} \mathrm{N}\right)_{2}\left(\mathrm{~N}^{\wedge} \mathrm{N}\right)\right] \mathrm{PF}_{6}(\mathbf{G})$ was prepared using again the fluorinated 2-arylpyridine pro-ligands 1-6, 4,4'-dimethyl-2,2'-bipyridine being used as the diimine ancillary ligand following the reported two-step procedure (Scheme 3). ${ }^{11}$ Complexes G1-G6 were isolated in $64-74 \%$ yields as yellow air-stable solids, and were characterized by NMR spectroscopy and high-resolution MALDI mass spectrometry. The complex G1, prepared from non-arylated 2-(2,4-difluorophenyl)-5-(trifluoromethyl)pyridine has been previously employed as a catalyst in photocatalytic water reduction, but there was no studies devoted to its luminescent properties. ${ }^{18}$
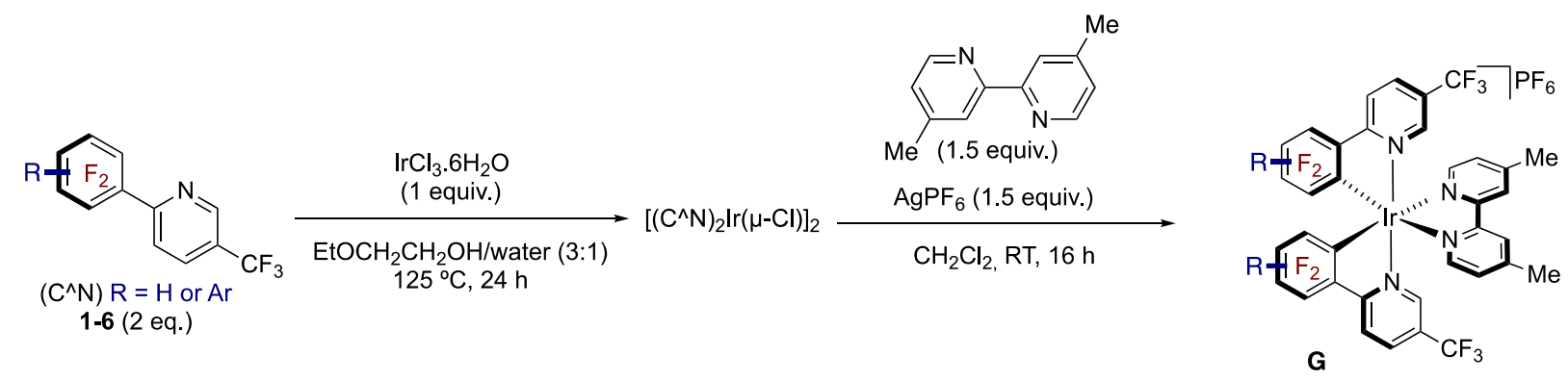
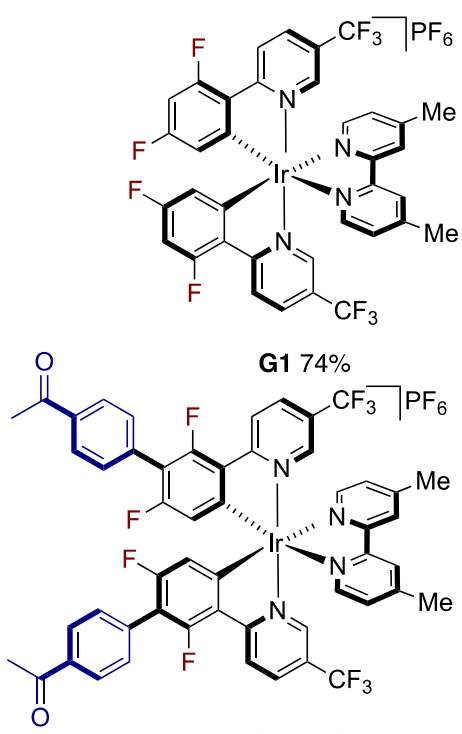

G4 $64 \%$

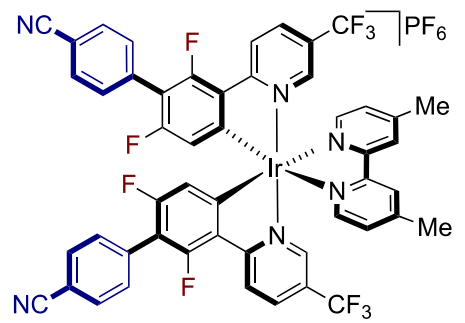

G2 $70 \%$

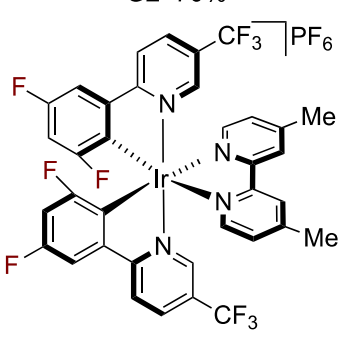

G5 $70 \%$
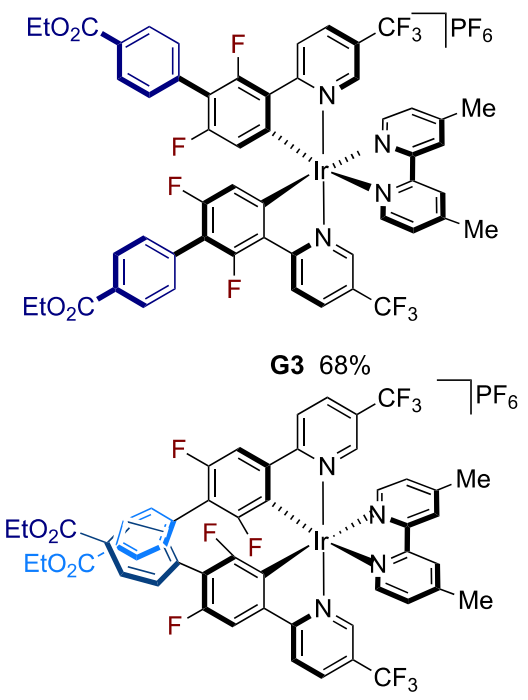

G6 $64 \%$

Scheme 3. Preparation of Complexes G1-G6 with 4,4'-Dimethyl-2,2'-bipyridine as Ancillary Ligand.

X-ray Crystal Structures. Single crystals of F2, F5, F6, G3, and G5 suitable for X-ray analysis were grown by slow diffusion of hexane into a $\mathrm{CH}_{2} \mathrm{Cl}_{2}$ solution of the respective complexes. The X-ray crystal structures of the neutral complexes F2, F5 and F6 and the cationic complexes $\mathbf{G 3}$ and G5 are depicted in Figure 2. Selected bond distances and bond angles as well as selected bite angles are tabulated in Table 1. All complexes, neutral and cationic, exhibited distorted octahedral geometries, with the two $\mathrm{C}^{\wedge} \mathrm{N}$ ligands adopting a $\mathrm{C}, \mathrm{C}$ - 
cis, and N,N-trans configuration, similar to that of the archetype complexes. ${ }^{4 a}{ }^{\mathrm{a}}$ For neutral complexes, the oxygen atom of the picolinate ligand is located trans to the C-ligand, as found in the precursor complex F1. ${ }^{9}$ The $\mathrm{Ir}-\mathrm{C}$ and $\mathrm{Ir}-\mathrm{N}$ bond distances in $\mathbf{F} 2$ are in the same range to those of the unsubstituted complex F1. The average $\operatorname{Ir}-\mathrm{N}(2.052 \AA)$ and $\operatorname{Ir}-\mathrm{C}(2.019, \AA)$ bond distances in the $\mathrm{C}^{\wedge} \mathrm{N}$ ligands of F6 are longer that those observed for the 2-(4,6difluorophenyl)pyridinato derivatives F1 and F2. The aryl pendant is not coplanar with the $\mathrm{C}^{\wedge} \mathrm{N}$ ligand, the torsion angles between the plane of the incorporated aryl group and that of cyclometalated phenyl ring of the two $\mathrm{C}^{\wedge} \mathrm{N}$ ligands, are $64.30(4)^{\circ}$ and $46.20(4)^{\circ}$ and $68.20(12)^{\circ} / 61.40(13)^{\circ}$ for $\mathbf{F 2}$ and F6, respectively. For cationic complexes, the average Ir-Cppy (2.021 $\AA$ ) and Ir-Nppy (2.053 $\AA$ ) bond distances of G5 are elongated, with respect to those in complex G3. The added aryl group in $\mathbf{G 3}$ displays a similar twisted conformation observed for $\mathbf{F}$ series of complexes: the plane of the aryl ring relative to that of the $\mathrm{C}$ connected phenyl displays dihedral angles of $61.30(8)^{\circ}$ and $53.00(9)^{\circ}$. Importantly, the distance between two iridium centers for adjacent complexes in the crystal packing varies slightly from $8.150 \AA$ (F1) ${ }^{9}$ to $9.044 \AA$ (F2) while a more significant increase is observed going from $\mathbf{F 5}$ to $\mathbf{F 6},(9.917 \AA$ to $14.157 \AA$ ). Notably, G3 exhibits the longer intermetallic distance of $15.034 \AA$, longer than that found for G5 (10.080 $)$ ) showing the dramatic influence of the presence of the bulky $p-\mathrm{C}\left(\mathrm{O}_{2} \mathrm{Et}\right)-\mathrm{C}_{6} \mathrm{H}_{4}$ group in this case. This distance is significantly greater than to the maximum values reported for the related 4-substituted pyridine cationic complexes which do not exceed $11 \AA .{ }^{12}$ These results illustrate the impact of the location (phenyl vs. pyridyl rings of $\mathrm{C}^{\wedge} \mathrm{N}$-ligands) of the appended aryl group in the solid state. 


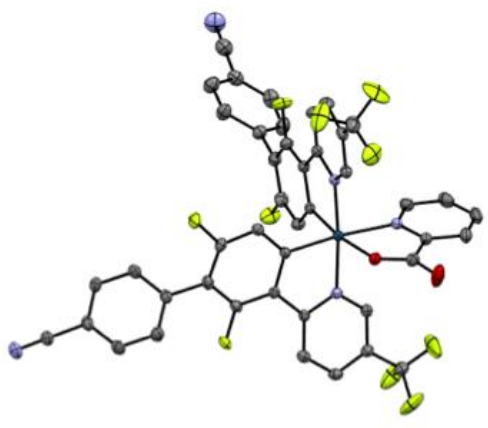

X-Ray structure of F2

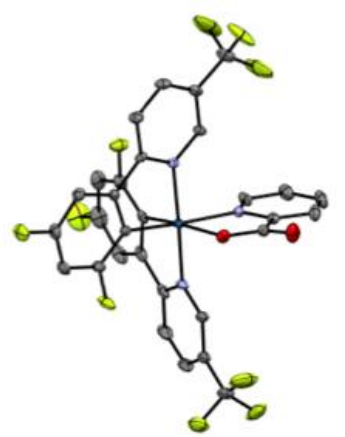

X-Ray of structure of F5

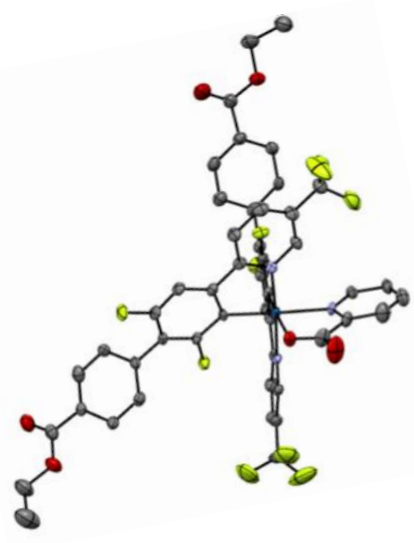

X-Ray of structure of F6

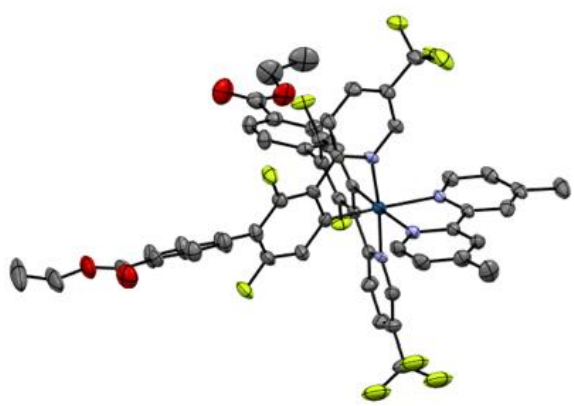

X-Ray structure of G3

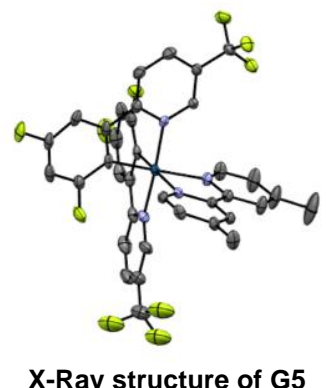

X-Ray structure of G5

Figure 2. Solid State Structures of Complexes F2, F5, F6, G3 and G5. Hydrogen atoms, solvent and counter anion are omitted for clarity. Thermal ellipsoids are at the 50\% probability level.

\section{Electrochemical studies.}

The representative voltammograms of complexes $\mathbf{F}$ and $\mathbf{G}$ are depicted in Figures $\mathbf{S} 1$ and S2, respectively, and the corresponding numerical data are summarized in Table S1 and S2 (see SI). Complexes $\mathbf{F}$ show irreversible (complexes F1, F3 and F4) or quasi-irreversible (complexes F2, F5 and F6) oxidation waves in their cyclic voltammograms in $\mathrm{CH}_{2} \mathrm{Cl}_{2}(0.1 \mathrm{M}$ of $n-\mathrm{Bu}_{4} \mathrm{NPF}_{6}$ as the supporting electrolyte at a scan rate of $100 \mathrm{mV} \mathrm{s}^{-1}$ and using ferrocene/ferrocenium $\left(\mathrm{Fc} / \mathrm{Fc}^{+}\right)$as the internal reference). The oxidation waves of F1-F4 are in the range of +1.08 to $+1.25 \mathrm{~V} v s$. $\mathrm{Fc} / \mathrm{Fc}^{+}$, which can be attributed to the $\operatorname{Ir}(\mathrm{III}) /(\mathrm{IV})$ redox couple with contributions from the $\mathrm{C}^{\wedge} \mathrm{N}$ ligands. ${ }^{10 \mathrm{a}}$ Upon the addition of aryl groups to the 5position of the phenyl ring, the oxidation waves of F2-F4 are slightly catholically shifted, reflecting the moderately increased electron density due to the presence of appended aryl substituents. The irreversible reduction waves are very comparable to one another. The HOMO-LUMO gaps, calculated from these potentials are comparable to that previously found for F1. ${ }^{9}$ Both complexes F5 and F6 exhibit a quasi-reversible single-electron oxidation wave, a notably less positive oxidation potential than the 4,6-difluoro-based complexes, illustrating the electronic effect of the 3,5-fluorine substitution of the $\mathrm{C}^{\wedge} \mathrm{N}$ ligands 
on the anodic potential. The $\mathbf{G}$ series of $\operatorname{Ir}(\mathrm{III})$ metal complexes, which are cationic, display less obvious oxidation peak, due to the reduction of electron density at the metal center compared to the $\mathbf{F}$ series of charge-neutral metal complexes. A feature which has been observed for bis-tridentate $\operatorname{Ir}(\mathrm{III})$ complexes, going from the charge-neutral to the cationic forms upon methylation. ${ }^{19}$

Table 1. Selected Bond Lengths ( $\AA$ ) and Angles (deg) for Complexes F1, F2, F5, F6, G3 and G5 with Estimated Standard Deviations (es's) Given in Parentheses.

\begin{tabular}{|c|c|c|c|c|c|c|c|}
\hline & \multicolumn{4}{|c|}{ Bond length $(\AA)$} & \multicolumn{3}{|c|}{ Bite angle $(\stackrel{\circ}{)})$} \\
\hline & Ir-C & $\operatorname{Ir}-\mathrm{N}$ & Ir $-\mathrm{N}_{\text {pic }}$ & Ir-O & $\mathrm{C}_{\mathrm{C} N \mathrm{~N}^{-}}-\mathrm{Ir}-\mathrm{N}_{\mathrm{C}^{\wedge N} \mathrm{~N}}$ & $\mathrm{~N}_{\text {pic }}-\mathrm{Ir}-\mathrm{O}$ & $\Theta^{[a]}$ \\
\hline $\mathbf{F} \mathbf{1}^{9}$ & $\begin{array}{l}1.988(4) \\
2.007(4)\end{array}$ & $\begin{array}{l}2.039(3) \\
2.047(3)\end{array}$ & $2.154(3)$ & $2.149(3)$ & $\begin{array}{l}80.38(16) \\
80.84(16)\end{array}$ & $76.65(13)$ & - \\
\hline F2 & $\begin{array}{l}1.999(3) \\
2.006(3)\end{array}$ & $\begin{array}{l}2.034(2) \\
2.054(2)\end{array}$ & $2.135(2)$ & $2.140(18)$ & $\begin{array}{l}80.67(10) \\
80.88(10)\end{array}$ & $77.51(8)$ & $\begin{array}{l}64.30(4) / \\
46.20(4)\end{array}$ \\
\hline F5 & $\begin{array}{l}2.009(3) \\
2.027(3)\end{array}$ & $\begin{array}{l}2.048(2) \\
2.038(2)\end{array}$ & $2.128(2)$ & $2.136(2)$ & $\begin{array}{l}79.57(10) \\
80.21(11)\end{array}$ & $77.70(8)$ & - \\
\hline F6 & $\begin{array}{l}2.011(7) \\
2.033(7)\end{array}$ & $\begin{array}{l}2.053(6) \\
2.051(6)\end{array}$ & $2.126(6)$ & $2.138(6)$ & $\begin{array}{l}80.50(3) \\
80.60(3)\end{array}$ & $77.40(2)$ & $\begin{array}{l}68.20(12) \\
61.40(13)\end{array}$ \\
\hline & $\mathrm{Ir}-\mathrm{C}$ & $\operatorname{Ir}-\mathrm{N}_{\mathrm{C}^{\wedge N}}$ & \multicolumn{2}{|c|}{$\operatorname{Ir}-\mathrm{N}_{\mathrm{N}^{\wedge} \mathrm{N}}$} & $\mathrm{C}-\mathrm{Ir}-\mathrm{N}_{\mathrm{C}^{\wedge N}}$ & $\mathrm{~N}_{\mathrm{N}^{\wedge} \mathrm{N}}-\mathrm{Ir}-\mathrm{N}_{\mathrm{N}^{\wedge} \mathrm{N}}$ & $\Theta^{[a]}$ \\
\hline G3 & $\begin{array}{l}2.014(5) \\
2.019(5)\end{array}$ & $\begin{array}{l}2.043(4) \\
2.048(4)\end{array}$ & \multicolumn{2}{|c|}{$\begin{array}{l}2.138(4) \\
2.153(4)\end{array}$} & $\begin{array}{c}80.50(2) \\
80.11(19)\end{array}$ & $76.54(17)$ & $\begin{array}{l}61.30(8) \\
53.00(9)\end{array}$ \\
\hline G5 & $\begin{array}{l}2.020(5) \\
2.023(5)\end{array}$ & $\begin{array}{l}2.051(5) \\
2.055(4)\end{array}$ & \multicolumn{2}{|c|}{$\begin{array}{l}2.118(4) \\
2.131(4)\end{array}$} & $\begin{array}{l}80.40(2) \\
79.90(2)\end{array}$ & $77.34(16)$ & - \\
\hline
\end{tabular}

${ }^{[a]}$ the dihedral angle between the pendant aryl ring and fluorinated ring in $\mathrm{C}^{\wedge} \mathrm{N}$ ligands.

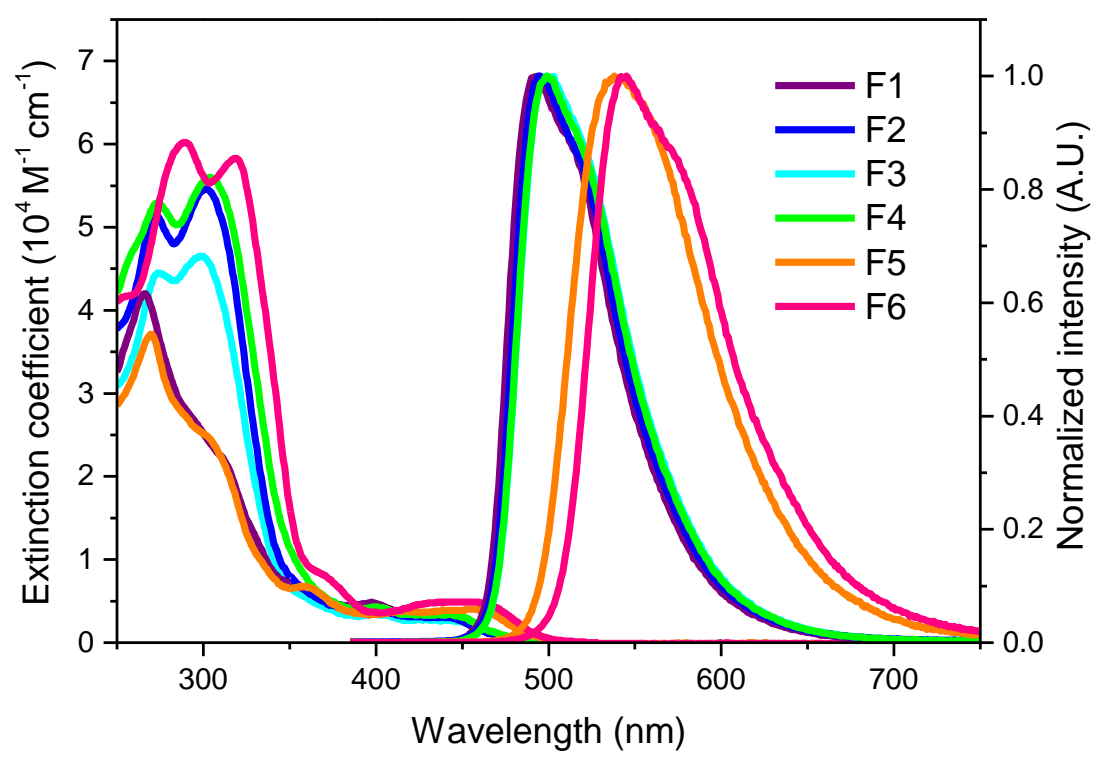

Figure 3. Absorption and emission spectra (recorded in $\mathrm{CH}_{2} \mathrm{Cl}_{2}$ at $298 \mathrm{~K}, \lambda_{\text {exc }}=370 \mathrm{~nm}$ ) of the studied charge-neutral Iridium(III) complexes F1-F6. 
Table 2. Essential photophysical data of the studied bis-cyclometalated Ir(III) complexes F1F6

$\begin{array}{llllll} & \text { abs } \lambda_{\max } / \mathrm{nm}\left(\varepsilon / 10^{4} \mathrm{M}^{-1} \mathrm{~cm}^{-1}\right)^{[\mathrm{a}]} & \mathrm{em} \lambda_{\max } / \mathrm{nm}^{[\mathrm{b}]} & \Phi / \%{ }^{[\mathrm{b}, \mathrm{c}]} & \tau_{\mathrm{obs}} / \mu \mathrm{s}^{[\mathrm{b}]} & \tau_{\mathrm{rad}} / \mu \mathrm{s}^{[\mathrm{b}]} \\ \text { F1 }^{[\mathrm{d}]} & 266(4.18), 312(2.23), 398(0.49), 443(0.32) & 492,516(\mathrm{sh}) & 65 & 1.33 & 2.0 \\ \text { F2 } & 272(5.16), 302(5.45), 400(0.41), 441(0.31) & 495,518(\mathrm{sh}) & 100 & 1.41 & 1.4 \\ \text { F3 } & 274(4.44), 300(4.66), 402(0.36), 447(0.27) & 499,520(\mathrm{sh}) & 100 & 1.48 & 1.5 \\ \text { F4 } & 273(5.29), 304(5.60), 400(0.43), 444(0.34) & 499,519(\mathrm{sh}) & 98 & 1.49 & 1.5 \\ \text { F5 } & 270(3.71), 307(2.40), 359(0.82), 461(0.38) & 537,560(\mathrm{sh}) & 90 & 3.51 & 3.9 \\ \text { F6 } & 289(6.02), 320(5.84), 371(0.82), 462(0.51) & 544,576(\mathrm{sh}) & 88 & 4.55 & 5.2\end{array}$

[a] UV-Vis spectra was recorded in $\mathrm{CH}_{2} \mathrm{Cl}_{2}$ at a conc. of $10^{-5} \mathrm{M}$ at $\mathrm{RT}$. [b] PL spectra, lifetime and quantum yields were recorded in degassed $\mathrm{CH}_{2} \mathrm{Cl}_{2}$ at a conc. of $10^{-5} \mathrm{M}$ at RT. [c] Coumarin 153 (C153) in EtOH (Q.Y. = 58\% and $\lambda \max =530 \mathrm{~nm}$ ) was employed as quantum yields standard. [d] our studies, for a better comparison.

Electronic absorption and emission properties. The photophysical properties of complexes F1-F6 are summarized in Table 2, and their UV-vis. absorption and emission spectra are illustrated in Figure 3. The electronic absorption spectrum $\left(\mathrm{CH}_{2} \mathrm{Cl}_{2}\right)$ of $\mathbf{F 1}$ is comparable to that of the Firpic ${ }^{5 e, 9}$ displaying an intense intraligand (IL) band in the far UV (266 nm), and a moderately intense band at lower-energy $(312 \mathrm{~nm})$ due to $\pi-\pi^{*}$ transition of the $\mathrm{C}^{\wedge} \mathrm{N}$ ligands. The weak low-energy bands at 398 and $443 \mathrm{~nm}$ are typically attributed to metal-to-ligand charge transfer and ligand-to-ligand charge transfer (MLCT/LLCT) transitions. The introduction of the electron-withdrawing $\mathrm{CF}_{3}$ group on the pyridyl ring leads to a modest bathochromic shift of the lowest-energy absorption, with respect to FIrpic. The profiles of the absorption bands of complexes F2-F4 are also similar to each other, showing a broad and red-shifted intense band in the UV region (260-360 nm), due to the additional aryl group. The spectrum of F5, where the substitution pattern of the fluorine atoms is modified, is slightly perturbed, bathochromic shifted compared to that of F1. The arylated complex F6, shows a comparable behavior to F2-F4, the weaker band at wavelength longer than $400 \mathrm{~nm}$ has greater molar extinction coefficients, a feature also observed for the parent complex F5. Upon photo-excitation at $\lambda_{\text {exc }}=370 \mathrm{~nm}, \mathrm{CH}_{2} \mathrm{Cl}_{2}$ solutions of the $\mathbf{F 1 - F 4}$ complexes display intense luminescence into the blue-green region. Upon going from the unsubstituted FIrpic $\left(\lambda_{\mathrm{em}}=468,495 \mathrm{sh} \mathrm{nm}\right)^{5 \mathrm{e}}$ to the $5-\mathrm{CF}_{3}$-substituted derivative $\mathbf{F 1}$, the room temperature emission spectrum in dichloromethane exhibits two emission peak maxima at $\lambda=492 \mathrm{~nm}$ and $516 \mathrm{~nm}$, similar in shape but red-shifted by $24 \mathrm{~nm}$. The emission band of F2 $\left(\Delta \lambda_{\mathrm{em}}=3 \mathrm{~nm}\right)$ and those of $\mathbf{F 3}$ and $\mathbf{F 4}\left(\Delta \lambda_{\mathrm{em}}=7 \mathrm{~nm}\right)$ is negligible shifted when compared to the parent $\mathbf{F 1}$. As the precursor complex, their emission arises from a mixture of ${ }^{3} \mathrm{MLCT}$ and ${ }^{3} \mathrm{LC}$ (ligand centered) transitions, with lifetimes found in the region of $1.4 \mu \mathrm{s}^{5 \mathrm{e}}$ This negligible impact 
observed upon arylation at the 5-position of the 4,6-difluorophenyl ring on emission arises from the almost orthogonal conformation of the appended aryl groups observed by X-ray studies and also reported in previous studies. ${ }^{10 \mathrm{e}}$ Notably, arylation leads to a significant enhancement of the luminescence quantum yields in dilute solution, PLQY of F2, F3, and F4 are increased up to unity. The substituted 3,5-difluorophenylpyridinato-based complex F6 displays an emission band peaking at $544 \mathrm{~nm}$, red-shifted by $7 \mathrm{~nm}$ compared to that of the precursor 2-(3,5-difluorophenyl)-5-(trifluoromethyl)pyridine complex F5, both complexes emit in the green region with a similar quantum yield. The same bathochromic shift of $45 \mathrm{~nm}$ found for $\mathbf{F 5}$ relative to $\mathbf{F 1}$ and $\mathbf{F 3}$ with respect to $\mathbf{F 6}$ is attributed to the reduced impact of the electronic effect of 3,5-disubstituted fluorine atoms. The increase of luminescence lifetimes up to $4.55 \mu$ s for $\mathbf{F 6}$ suggests a more pronounced ${ }^{3} \mathrm{LC}$ character, the quantum yields being significantly unaffected despite the observed red-shift. The improvement of QY in solution-state upon introduction of an aryl substituent in F2-F4 is intriguing. One possible explanation for this feature could be an increase of the radiative rate constant due to a higher degree of rigidity of these congested molecules, compared to the unsubstituted complex F1. The bulkiness would inhibit the attainment of a coplanar conformation and lowers the extension the $\pi$-conjugation of the system since the emission wavelength and lifetimes are relatively unaffected in F2-F4. It may be noted that for complex F6 having a different fluorine substitution pattern, the quantum yield does not significantly drop off despite the decrease of the emission energy, probably due to the counteracting effect of the aryl functionalization which would be expected to have a similar positive impact on $\phi$ as found for F2-F4. Moreover, our results demonstrate that the ligand modification gives rise to the enhancement of the luminescence efficiency whatever the location of the added aryl group either onto the phenyl ring or the pyridine ring of $\mathrm{C}^{\wedge} \mathrm{N}$ ligand for the aryl-substituted pyridine ligand of FIrpic. ${ }^{10 a}$ 


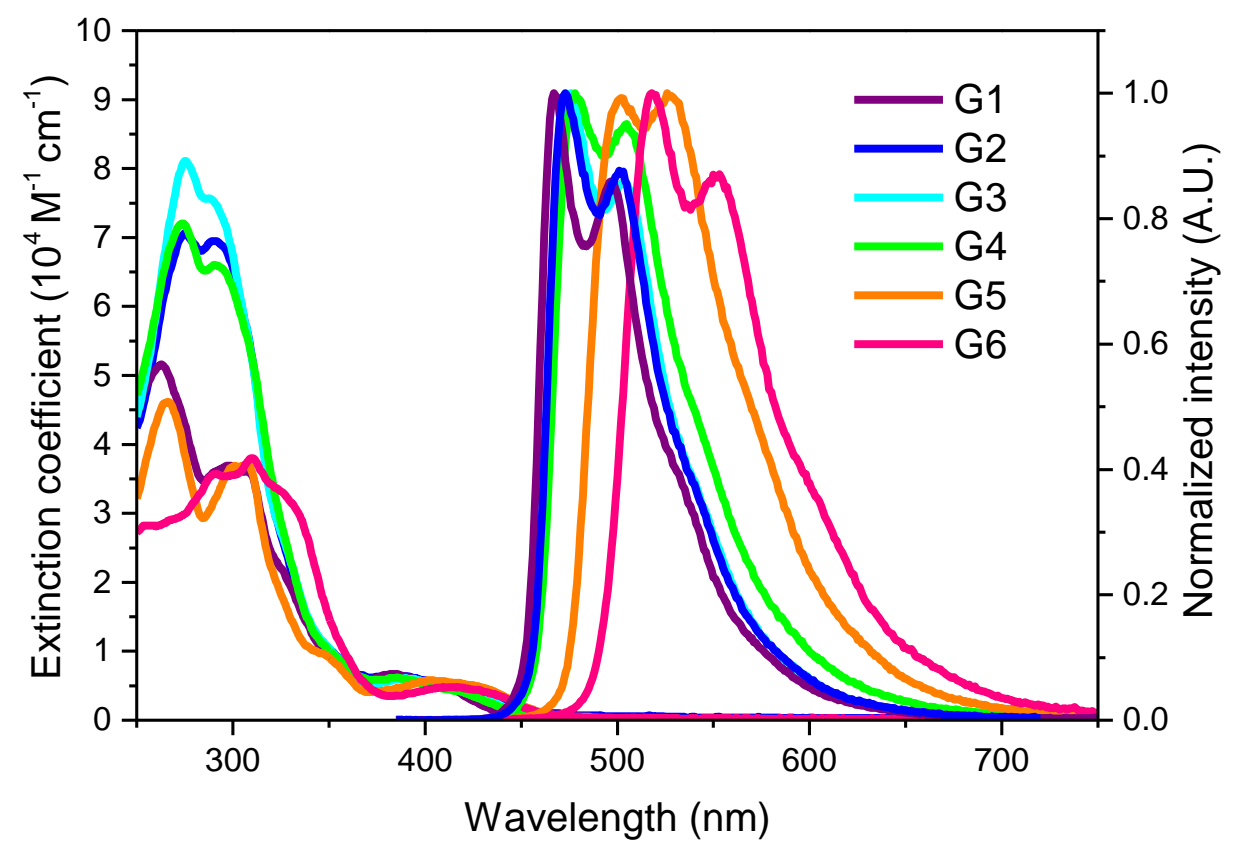

Figure 4. Absorption and emission spectra (recorded in $\mathrm{CH}_{2} \mathrm{Cl}_{2}$ at $298 \mathrm{~K}, \lambda_{\mathrm{exc}}=370 \mathrm{~nm}$ ) of the studied charge-neutral Iridium(III) complexes G1-G6

Table 3. Essential photophysical data of the studied bis-cyclometalated cationic $\operatorname{Ir}(\mathrm{III})$ complexes G1-G6

\begin{tabular}{llllll} 
& $\operatorname{abs} \lambda_{\max } / \mathrm{nm}\left(\varepsilon / 10^{4} \mathrm{M}^{-1} \mathrm{~cm}^{-1}\right)^{[\mathrm{a}]}$ & $\mathrm{em} \lambda_{\max } / \mathrm{nm}^{[\mathrm{b}]}$ & $\Phi / \% \%^{[\mathrm{b}, \mathrm{cc}]}$ & $\left.\tau_{\mathrm{obs}} / \mu\right)^{[\mathrm{b}]}$ & $\tau_{\mathrm{rad}} / \mu \mathrm{s}^{[\mathrm{b}]}$ \\
\hline G1 & $263(5.14), 309(3.62), 327(2.16), 416(0.44)$ & 468,497 & 100 & 2.47 & 2.5 \\
G2 & $275(7.07), 291(6.95), 388(0.66), 420(0.47)$ & 473,502 & 83 & 2.69 & 3.2 \\
G3 & $276(8.12), 290(7.57), 391(0.62), 418(0.50)$ & 476,504 & 100 & 2.63 & 2.6 \\
G4 & $274(7.20), 293(6.59), 386(0.60), 419(0.42)$ & 478,505 & 100 & 2.42 & 2.4 \\
G5 & $266(4.62), 308(3.70), 349(0.92), 405(0.58), 426(0.50)$ & 502,527 & 86 & 4.06 & 4.7 \\
G6 & $290(3.57), 310(3.80), 331(3.12), 416(0.50)$ & 519,553 & 70 & 8.39 & 12.0 \\
\hline
\end{tabular}

[a] UV-Vis spectra were recorded in $\mathrm{CH}_{2} \mathrm{Cl}_{2}$ at a conc. of $10^{-5} \mathrm{M}$ at $\mathrm{RT}$. [b] PL spectra, lifetime and quantum yields were recorded in degassed $\mathrm{CH}_{2} \mathrm{Cl}_{2}$ at a conc. of $10^{-5} \mathrm{M}$ at RT. [c] Coumarin 102 (C102) in $\mathrm{MeOH}$ (Q.Y. $=87 \%$ and $\lambda \max =480 \mathrm{~nm})$ and Coumarin $153(\mathrm{C} 153)$ in $\mathrm{EtOH}(\mathrm{Q} . \mathrm{Y} .=58 \%$ and $\lambda \max =530 \mathrm{~nm})$ was employed as quantum yields standard.

The second series of cationic complexes $\mathbf{G}$ dissolve in $\mathrm{CH}_{2} \mathrm{Cl}_{2}$ to give yellow orange solutions at $298 \mathrm{~K}$. The electronic absorption spectra of G1 exhibit an intense absorption band at $260-360 \mathrm{~nm}$ and a moderately intense band at $360-450 \mathrm{~nm}$ with a $\lambda_{\max }$ at ca. $400 \mathrm{~nm}$ in dichloromethane (Figure 4). The complexes G2-G4 exhibit similar absorption spectra but with the observation of intense and very broad high-energy absorption bands from $270 \mathrm{~nm}$ to $380 \mathrm{~nm}$ due to the presence of the additional aromatic groups. As reported in the spectroscopic studies on related iridium(III) complexes, ${ }^{10 \mathrm{e}}$ the high-energy absorption bands 
are assigned as $\pi \rightarrow \pi^{*}$ intraligand transitions of the $\mathrm{C}^{\wedge} \mathrm{N}$ and $\mathrm{N}^{\wedge} \mathrm{N}$ ligands, as well as lowerenergy absorption bands in the visible region are assigned as the admixture of intraligand $\left[\pi \rightarrow \pi^{*}\right]$ transitions and metal-to-ligand charge transfer (MLCT) [d $\left.\pi(\mathrm{Pt}) \rightarrow \pi^{*}(\mathrm{dmbpy})\right]$ transitions. Their electronic absorption data have been summarized in Table 3 . The absorption tail $(\sim 450-500 \mathrm{~nm})$ is found to show insignificant changes in the absorption profiles, these weaker absorption bands are assigned to spin-forbidden $\left({ }^{3} \mathrm{MLCT} /{ }^{3} \mathrm{LC}\right)$ transitions. As depicted in Figure 4, upon photo-excitation at $\lambda_{\text {exc }}=370 \mathrm{~nm}$, all $\operatorname{Ir}(\mathrm{III})$ complexes show bright luminescence in fluid solution $\left(\mathrm{CH}_{2} \mathrm{Cl}_{2}\right)$ at $298 \mathrm{~K}$. The profiles of the emission bands are found to be insensitive to the nature of the appended aryl groups of $\mathrm{C}^{\wedge} \mathrm{N}$ ligands and to the location of fluorine atoms. The complexes G1-G4 show a small difference in emission peak wavelengths from 468 (497sh) to $478 \mathrm{~nm}(505 \mathrm{sh})$. The emission ranges from blue to green, the red-shifted emission being observed for G5 (502 nm) and G6 (519 $\mathrm{nm}$ ), a shift arising from the 3,5-fluorine substitution pattern, a feature also found for the related neutral complexes F5-F6. As expected, the different electronic effect of the fluorine in F5-6 has an impact on the nature of the emissive excited state which gives rise to longer lifetimes (see Table 3). By comparison, note that the related complex $\left[\operatorname{Ir}(\mathrm{Phppy})_{2}(\mathrm{bpy})\right] \mathrm{PF}_{6}$, (where Phppy is 2-([1,1'-biphenyl]-3-yl)pyridine), bearing a phenyl group trans to the $\mathrm{Ir}-\mathrm{C}_{\mathrm{C}^{\wedge} \mathrm{N}}$ bond exhibits a yellow-orange emission with a $\Phi_{\mathrm{PL}}$ of $13 \%$ in $\mathrm{CH}_{2} \mathrm{Cl}_{2}{ }^{12}$. Clearly, the combined effect of fluorine positioning in phenyl ring and a 5- $\mathrm{CF}_{3}$-substitution of dF-ppy leads to a noteworthy improvement of PLQY values with respect to the parent complex $\left[\operatorname{Ir}(\mathrm{ppy})_{2}(\mathrm{bpy})\right] \mathrm{PF}_{6}$ (bpy $=2,2^{\prime}$-bipyridine). Moreover, our study shows an exceptionally high quantum yield values (unitary) for $\mathbf{G 3}$ and G4, the steric bulk and/or electronic effect provided by the incorporated aryl group does not affect the luminescence efficiency which are similar to the parent complex G1. However, the positive impact, clearly seen in the $\mathbf{F}$ series, cannot be evidenced in the present case. Although G2 displays an apparently erratic $\phi$ value (83\%), compared to $\mathbf{G 1}$ and G3-4, it exhibits a bright luminescence, the $\phi$ value being in the same range than that of its congeners. In the other hand, a slight decrease of $\phi$ is found for G6, with respect to G5, a trend already observed upon going from F5 to F6, which could be attributed to the decrease of emission energy.

\section{CONCLUSION}

Our catalytic approach namely regioselective Pd-catalyzed $\mathrm{C}-\mathrm{H}$ bond arylations applied to 2(2,4-difluorophenyl)-5-(trifluoromethyl)pyridine (1) and 2-(3,5-difluorophenyl)-5- 
(trifluoromethyl)pyridine (5) allows the access to two families of functionalized Ir(III) complexes, i.e. both the charge-neutral and cationic complexes with generalized empirical formula $\left[\operatorname{Ir}\left(\mathrm{C}^{\wedge} \mathrm{N}\right)_{2}\left(\mathrm{~N}^{\wedge} \mathrm{O}\right)\right](\mathbf{F})$ and $\left[\operatorname{Ir}\left(\mathrm{C}^{\wedge} \mathrm{N}\right)_{2}\left(\mathrm{~N}^{\wedge} \mathrm{N}\right)\right] \mathrm{PF}_{6}$. $(\mathbf{G})$, respectively. The positions of the fluorine atoms around the cyclometalated phenyl ring are different in the two series (F1F4 and G1-G4 vs. F5, F6, G5, G6). The incorporation of various para-substituted aryl appendages with an electron-withdrawing group $\left(\mathrm{CN}, \mathrm{CO}_{2} \mathrm{Et}, \mathrm{C}(\mathrm{O}) \mathrm{Me}\right)$ occurs regioselectively at the $\mathrm{C} 3$ - or C4-positions of the difluorobenzene ring of parent ligands $\mathbf{1}$ and 5, respectively. X-ray crystal studies of F2, F5, F6, G3, and G5 indicate that the intermolecular interactions are reduced, as the result of the steric bulk provided by the additional aromatic groups. The intermolecular Ir...Ir distance between adjacent complexes in crystals goes up to $15.034 \AA$, demonstrating the benefit of this approach in terms of bulkiness. The photophysical properties of the resulting complexes have been studied. All the investigated complexes show bright photoluminescence at room temperature in $\mathrm{CH}_{2} \mathrm{Cl}_{2}$ solution. Within the same series, the functionalized complexes display almost identical emission despite the different aryl substitution. An increase of the photoluminescence quantum yield is observed in all cases, showing the interest of such ligand design. Moreover, these functional groups $\left(\mathrm{CN}, \mathrm{CO}_{2} \mathrm{Et}, \mathrm{C}(\mathrm{O}) \mathrm{Me} \ldots\right)$ might be further used as linker and grafting agents; or to modify the properties of the complexes e.g., hydrophilicity, lipophilicity, key features in the fabrication of devices. This work represents a convenient route for the addition of functional and bulky groups to cyclometalated $\operatorname{Ir}(\mathrm{III})$ complexes, potentially useful for applications in opto-electronics. Studies on other metal systems are currently under way.

\section{EXPERIMENTAL SECTION}

General Information. All reactions were carried out under argon atmosphere with standard Schlenk techniques. DMA and ethoxyethanol were purchased from Acros Organics and were not purified before use. ${ }^{1} \mathrm{H},{ }^{13} \mathrm{C}$ and ${ }^{19} \mathrm{~F}$ NMR spectra were recorded on Bruker AV III 400 MHz NMR spectrometer equipped with BBFO probehead. Chemical shifts $(\delta)$ were reported in parts per million relative to residual chloroform $\left(7.28 \mathrm{ppm}\right.$ for ${ }^{1} \mathrm{H} ; 77.23 \mathrm{ppm}$ for $\left.{ }^{13} \mathrm{C}\right)$, constants were reported in Hertz. ${ }^{1} \mathrm{H}$ NMR assignment abbreviations were the following: singlet (s), doublet (d), triplet (t), quartet (q), doublet of doublets (dd), doublet of triplets (dt), and multiplet $(\mathrm{m})$. All reagents were weighed and handled in air. HRMS were recorded on a Bruker Ultraflex III mass spectrometer at the corresponding facilities of the Centre Régional de Mesures Physiques de l'Ouest, Université de Rennes 1 (CRMPO). Elemental Analysis 
were recorded on a Thermo Fisher FLASH 1112 at the corresponding facilities of the CRMPO. UV-Vis spectra were recorded on a HITACHI U-3900 spectrophotometer. The steady-state emission spectra and lifetime studies were measured with Edinburgh FL 900 photon-counting system. Both wavelength-dependent excitation and emission responses of the fluorimeter were calibrated. Spectral grade solvents (Merck) were used as received. To determine the photoluminescence quantum yield in solution, samples were degassed using at least three freeze-pump-thaw cycles. The solution quantum yields are calculated using the standard sample which has a known quantum yield. Cyclic voltammetry was conducted on a CHI621A Electrochemical Analyzer. $\mathrm{Ag} / \mathrm{Ag}^{+}\left(0.01 \mathrm{M} \mathrm{AgNO}_{3}\right)$ electrode was employed as reference electrode. The oxidation and reduction potentials were measured using a platinum working electrode with $0.1 \mathrm{M}$ of $\mathrm{NBu}_{4} \mathrm{PF}_{6}$ in $\mathrm{CH}_{2} \mathrm{Cl}_{2}$ and a gold wire with $0.1 \mathrm{M}$ of $\mathrm{NBu}_{4} \mathrm{PF}_{6}$ in THF, respectively. The potentials were referenced externally to the ferrocenium/ferrocene $\left(\mathrm{Fc}^{+} / \mathrm{Fc}\right)$ couple.

Preparation of the $\mathbf{P d C l}(\mathbf{d p p b})\left(\mathbf{C}_{3} \mathbf{H}_{5}\right)$ catalyst $^{20}$ : An oven-dried $40-\mathrm{mL}$ Schlenk tube equipped with a magnetic stirring bar under argon atmosphere, was charged with $\left[\mathrm{Pd}\left(\mathrm{C}_{3} \mathrm{H}_{5}\right) \mathrm{Cl}\right]_{2}(182 \mathrm{mg}, 0.5 \mathrm{mmol})$ and $\mathrm{dppb}(426 \mathrm{mg}, 1 \mathrm{mmol}) .10 \mathrm{~mL}$ of anhydrous dichloromethane were added, then the solution was stirred at room temperature for twenty minutes. The solvent was removed in vacuum. The yellow powder was used without purification. ${ }^{31} \mathrm{P}$ NMR $\left(81 \mathrm{MHz}, \mathrm{CDCl}_{3}\right) \delta(\mathrm{ppm})=19.3$ (s).

2-(2,4-Difluorophenyl)-5-(trifluoromethyl)pyridine (1): To a $15 \mathrm{~mL}$ oven dried Schlenk tube, 2-chloro-5-(trifluoromethyl)pyridine (1.81 g $10 \mathrm{mmol})$, (2,4-difluorophenyl)boronic acid (1.97 g, $12.5 \mathrm{mmol}), \mathrm{K}_{2} \mathrm{CO}_{3}(2.76 \mathrm{~g}, 20 \mathrm{mmol})$, toluene $(16 \mathrm{~mL}), \mathrm{MeOH}(2 \mathrm{~mL})$ water (2 $\mathrm{mL})$ and $\mathrm{PdCl}\left(\mathrm{C}_{3} \mathrm{H}_{5}\right)(\mathrm{dppb})(0.120 \mathrm{~g}, 0.2 \mathrm{mmol}, 2 \mathrm{~mol} \%)$ were successively added. The reaction mixture was evacuated by vacuum-argon cycles ( 5 times) and stirred at $110{ }^{\circ} \mathrm{C}$ (oil bath temperature) for 16 hours. After cooling the reaction at room temperature and concentration, the crude mixture was purified by flash chromatography on silica gel (EtOAcHeptane, 80:20) to afford the desired compound 1 (2.12 g, 82\%). The NMR data were consistent with those reported in the literature. ${ }^{21}$

2',6'-Difluoro-3'-(5-(trifluoromethyl)pyridin-2-yl)-[1,1'-biphenyl]-4-carbonitrile (2): To a $15 \mathrm{~mL}$ oven dried Schlenk tube, 2-(2,4-difluorophenyl)-5-(trifluoromethyl)pyridine (1) (259 
mg, $1.00 \mathrm{mmol}$ ), 4-bromobenzonitrile (273 mg, $1.5 \mathrm{mmol}$ ), PivOK (280 mg, 2 mmol), DMA $(3 \mathrm{~mL})$ and $\mathrm{PdCl}\left(\mathrm{C}_{3} \mathrm{H}_{5}\right)(\mathrm{dppb})(30 \mathrm{mg}, 0.05 \mathrm{mmol}, 5 \mathrm{~mol} \%)$ were successively added. The reaction mixture was evacuated by vacuum-argon cycles (5 times) and stirred at $150{ }^{\circ} \mathrm{C}$ (oil bath temperature) for 48 hours. After cooling the reaction at room temperature and concentration, the crude mixture was purified by flash chromatography on silica gel (EtOAcHeptane, 80:20) to afford the desired compound 2 (230 mg, 64\%). ${ }^{1} \mathrm{H}$ NMR (400 MHz, $\left.\mathrm{CDCl}_{3}\right) \delta(\mathrm{ppm}) 9.02(\mathrm{~d}, J=2.3 \mathrm{~Hz}, 1 \mathrm{H}), 8.14(\mathrm{td}, J=6.4,8.8 \mathrm{~Hz}, 1 \mathrm{H}), 8.04(\mathrm{dd}, J=2.4,8.4$ $\mathrm{Hz}, 1 \mathrm{H}), 7.93(\mathrm{dd}, J=2.2,8.3 \mathrm{~Hz}, 1 \mathrm{H}), 7.81(\mathrm{~d}, J=8.0 \mathrm{~Hz}, 2 \mathrm{H}), 7.66(\mathrm{~d}, J=8.0 \mathrm{~Hz}, 2 \mathrm{H})$, $7.22(\mathrm{t}, J=8.8 \mathrm{~Hz}, 1 \mathrm{H}) .{ }^{19} \mathrm{~F}\left\{{ }^{1} \mathrm{H}\right\} \mathrm{NMR}\left(376 \mathrm{MHz}, \mathrm{CDCl}_{3}\right) \delta(\mathrm{ppm})-62.4(\mathrm{~s}),-111.0(\mathrm{~d}, J=$ $9.4 \mathrm{~Hz}),-116.8(\mathrm{~d}, J=9.4 \mathrm{~Hz}) .{ }^{13} \mathrm{C}\left\{{ }^{1} \mathrm{H}\right\} \mathrm{NMR}\left(100 \mathrm{MHz}, \mathrm{CDCl}_{3}\right) \delta(\mathrm{ppm}) 160.5(\mathrm{dd}, J=$ 6.4, $253.8 \mathrm{~Hz}), 157.5(\mathrm{dd}, J=6.6,254.4 \mathrm{~Hz}), 155.6,146.6$ (q, $J=3.9 \mathrm{~Hz}), 133.8$ (q, $J=3.3$ $\mathrm{Hz}), 133.7,132.0,131.2,125.4(\mathrm{q}, J=33.2 \mathrm{~Hz}), 123.8(\mathrm{~d}, J=10.7 \mathrm{~Hz}), 123.5(\mathrm{q}, J=271,4$ $\mathrm{Hz}), 123.1(\mathrm{dd}, J=3.8,12.6 \mathrm{~Hz}), 118.5,117.3(\mathrm{t}, J=19.1 \mathrm{~Hz}), 112.6(\mathrm{dd}, J=3.7,22.8 \mathrm{~Hz})$, 112.4. Elemental analysis: calcd (\%) for $\mathrm{C}_{19} \mathrm{H}_{9} \mathrm{~F}_{5} \mathrm{~N}_{2}$ (360.29): C 63.34, H 2.52, N 7.78; found: C 63.09, H 2.65, N 7.98.

\section{Ethyl 2',6'-difluoro-3'-(5-(trifluoromethyl)pyridin-2-yl)-[1,1'-biphenyl]-4-carboxylate}

(3): To a $15 \mathrm{~mL}$ oven dried Schlenk tube, 2-(2,4-difluorophenyl)-5-(trifluoromethyl)pyridine (1) $(259 \mathrm{mg}, 1.00 \mathrm{mmol}$ ), ethyl 4-bromobenzoate (343 mg, $1.5 \mathrm{mmol}$ ), PivOK (280 mg, 2 mmol), DMA (3 mL) and $\mathrm{PdCl}\left(\mathrm{C}_{3} \mathrm{H}_{5}\right)(\mathrm{dppb})(30 \mathrm{mg}, 0.05 \mathrm{mmol}, 5 \mathrm{~mol} \%)$ were successively added. The reaction mixture was evacuated by vacuum-argon cycles ( 5 times) and stirred at $150{ }^{\circ} \mathrm{C}$ (oil bath temperature) for 48 hours. After cooling the reaction at room temperature and concentration, the crude mixture was purified by flash chromatography on silica gel (EtOAc-Heptane, 70:30) to afford the desired compound 3 (277 mg, 68\%). ${ }^{1} \mathrm{H}$ NMR (400 $\left.\mathrm{MHz}, \mathrm{CDCl}_{3}\right) \delta(\mathrm{ppm}) 9.00(\mathrm{~d}, J=2.3 \mathrm{~Hz}, 1 \mathrm{H}), 8.19(\mathrm{~d}, J=8.0 \mathrm{~Hz}, 2 \mathrm{H}), 8.11(\mathrm{td}, J=6.4,8.7$ $\mathrm{Hz}, 1 \mathrm{H}), 8.01(\mathrm{dd}, J=2.4,8.4 \mathrm{~Hz}, 1 \mathrm{H}), 7.93(\mathrm{dd}, J=2.1,8.4 \mathrm{~Hz}, 1 \mathrm{H}), 7.60(\mathrm{~d}, J=8.0 \mathrm{~Hz}$, $2 \mathrm{H}), 7.19(\mathrm{t}, J=8.7 \mathrm{~Hz}, 1 \mathrm{H}), 4.44(\mathrm{q}, J=7.1 \mathrm{~Hz}, 2 \mathrm{H}), 1.44(\mathrm{t}, J=7.1 \mathrm{~Hz}, 3 \mathrm{H}) .{ }^{19} \mathrm{~F}\left\{{ }^{1} \mathrm{H}\right\} \mathrm{NMR}$ $\left(376 \mathrm{MHz}, \mathrm{CDCl}_{3}\right) \delta(\mathrm{ppm})-62.4(\mathrm{~s}),-110.8(\mathrm{~d}, J=8.0 \mathrm{~Hz}),-116.6(\mathrm{~d}, J=8.0 \mathrm{~Hz}) .{ }^{13} \mathrm{C}\left\{{ }^{1} \mathrm{H}\right\}$ NMR (100 MHz, $\left.\mathrm{CDCl}_{3}\right) \delta(\mathrm{ppm}) 166.2,160.7(\mathrm{dd}, J=6.7,253.4 \mathrm{~Hz}), 157.7(\mathrm{dd}, J=6.9$, $253.9 \mathrm{~Hz}), 155.8,146.6(\mathrm{q}, J=4.0 \mathrm{~Hz}), 133.8(\mathrm{q}, J=3.6 \mathrm{~Hz}), 133.4,131.4(\mathrm{dd}, J=4.4,10.3$ $\mathrm{Hz}), 130.5,130.4,129.5,125.3(\mathrm{q}, J=33.2 \mathrm{~Hz}), 123.8(\mathrm{~d}, J=10.8 \mathrm{~Hz}), 123.5(\mathrm{q}, J=271.4$ $\mathrm{Hz}), 123.0(\mathrm{dd}, J=3.9,12.7 \mathrm{~Hz}), 118.2(\mathrm{t}, J=19.6 \mathrm{~Hz}), 112.5(\mathrm{dd}, J=3.8,22.8 \mathrm{~Hz}), 61.1$, 
14.3. Elemental analysis: calcd (\%) for $\mathrm{C}_{21} \mathrm{H}_{14} \mathrm{~F}_{5} \mathrm{NO}_{2}$ (407.34): $\mathrm{C}$ 61.92, $\mathrm{H}$ 3.46, N 3.44; found: C 62.08, H 3.59, N 3.21.

\section{1-(2',6'-Difluoro-3'-(5-(trifluoromethyl)pyridin-2-yl)-[1,1'-biphenyl]-4-yl)ethan-1-one}

(4): To a $15 \mathrm{~mL}$ oven dried Schlenk tube, 2-(2,4-difluorophenyl)-5-(trifluoromethyl)pyridine (1) $(259 \mathrm{mg}, 1.00 \mathrm{mmol}$ ), 4-bromoacetophenone (299 mg, $1.5 \mathrm{mmol})$, PivOK (280 mg, 2 mmol), DMA (3 mL) and $\mathrm{PdCl}\left(\mathrm{C}_{3} \mathrm{H}_{5}\right)(\mathrm{dppb})(30 \mathrm{mg}, 0.05 \mathrm{mmol}, 5 \mathrm{~mol} \%)$ were successively added. The reaction mixture was evacuated by vacuum-argon cycles ( 5 times) and stirred at $150{ }^{\circ} \mathrm{C}$ (oil bath temperature) for 48 hours. After cooling the reaction at room temperature and concentration, the crude mixture was purified by flash chromatography on silica gel (EtOAc-Heptane, 70:30) to afford the desired compound 4 (230 mg, 61\%). ${ }^{1} \mathrm{H}$ NMR (400 $\left.\mathrm{MHz}, \mathrm{CDCl}_{3}\right) \delta(\mathrm{ppm}) 9.01(\mathrm{~s}, 1 \mathrm{H}), 8.17-8.06(\mathrm{~m}, 3 \mathrm{H}), 8.02(\mathrm{dd}, J=2.3,8.4 \mathrm{~Hz}, 1 \mathrm{H}), 7.93$ $(\mathrm{d}, J=8.3 \mathrm{~Hz}, 1 \mathrm{H}), 7.64(\mathrm{~d}, J=7.9 \mathrm{~Hz}, 2 \mathrm{H}), 7.20(\mathrm{t}, J=8.7 \mathrm{~Hz}, 1 \mathrm{H}), 2.68(\mathrm{~s}, 3 \mathrm{H}) .{ }^{19} \mathrm{~F}\left\{{ }^{1} \mathrm{H}\right\}$ NMR $\left(376 \mathrm{MHz}, \mathrm{CDCl}_{3}\right) \delta(\mathrm{ppm})-62.4,-110.8(\mathrm{~d}, J=8.0 \mathrm{~Hz}),-116.6(\mathrm{~d}, J=8.0 \mathrm{~Hz})$. ${ }^{13} \mathrm{C}\left\{{ }^{1} \mathrm{H}\right\} \mathrm{NMR}\left(100 \mathrm{MHz}, \mathrm{CDCl}_{3}\right) \delta(\mathrm{ppm}) 197.6,160.7(\mathrm{dd}, J=6.7,253.5 \mathrm{~Hz}), 157.7(\mathrm{dd}, J$ $=6.9,254.0 \mathrm{~Hz}), 155.8,146.6(\mathrm{q}, J=4.0 \mathrm{~Hz}), 136.9,133.8(\mathrm{q}, J=3.5 \mathrm{~Hz}), 133.7,131.5(\mathrm{dd}$, $J=4.4,10.3 \mathrm{~Hz}), 130.7,128.3,125.3(\mathrm{q}, J=33.2 \mathrm{~Hz}), 123.8(\mathrm{~d}, J=10.7 \mathrm{~Hz}), 123.5(\mathrm{q}, J=$ $271.8 \mathrm{~Hz}), 123.0(\mathrm{dd}, J=4.0,12.7 \mathrm{~Hz}), 118.0(\mathrm{t}, J=19.6 \mathrm{~Hz}), 112.5(\mathrm{dd}, J=3.8,22.8 \mathrm{~Hz})$, 26.7. Elemental analysis: calcd (\%) for $\mathrm{C}_{20} \mathrm{H}_{12} \mathrm{~F}_{5} \mathrm{NO}$ (277.31): C 63.67, H 3.21, N 3.71; found: C 64.01, H 3.19, N 3.56.

2-(3,5-Difluorophenyl)-5-(trifluoromethyl)pyridine (5): To a $15 \mathrm{~mL}$ oven dried Schlenk tube, 2-chloro-5-(trifluoromethyl)pyridine (1.81 g $10 \mathrm{mmol})$, (3,5-difluorophenyl)boronic acid $(1.97 \mathrm{~g}, 12.5 \mathrm{mmol}), \mathrm{K}_{2} \mathrm{CO}_{3}(2.76 \mathrm{~g}, 20 \mathrm{mmol})$, toluene $(16 \mathrm{~mL}), \mathrm{MeOH}(2 \mathrm{~mL})$ water (2 $\mathrm{mL})$ and $\mathrm{PdCl}\left(\mathrm{C}_{3} \mathrm{H}_{5}\right)(\mathrm{dppb})(0.120 \mathrm{~g}, 0.2 \mathrm{mmol}, 2 \mathrm{~mol} \%)$ were successively added. The reaction mixture was evacuated by vacuum-argon cycles ( 5 times) and stirred at $110{ }^{\circ} \mathrm{C}$ (oil bath temperature) for 16 hours. After cooling the reaction at room temperature and concentration, the crude mixture was purified by flash chromatography on silica gel (EtOAcHeptane, 80:20) to afford the desired compound 5 (2.07 g, 80\%). ${ }^{1} \mathrm{H}$ NMR (400 MHz, $\left.\mathrm{CDCl}_{3}\right) \delta(\mathrm{ppm}) 8.96(\mathrm{~s}, 1 \mathrm{H}), 8.03(\mathrm{~d}, J=8.3 \mathrm{~Hz}, 1 \mathrm{H}), 7.81(\mathrm{~d}, J=8.3 \mathrm{~Hz}, 1 \mathrm{H}), 7.60(\mathrm{~d}, J=$ $7.2 \mathrm{~Hz}, 2 \mathrm{H}), 6.93(\mathrm{t}, J=8.7 \mathrm{~Hz}, 1 \mathrm{H}) .{ }^{19} \mathrm{~F}\left\{{ }^{1} \mathrm{H}\right\} \mathrm{NMR}\left(376 \mathrm{MHz}, \mathrm{CDCl}_{3}\right) \delta(\mathrm{ppm})-62.5(\mathrm{~S}),-$ $108.8(\mathrm{~S}) .{ }^{13} \mathrm{C}\left\{{ }^{1} \mathrm{H}\right\} \mathrm{NMR}\left(100 \mathrm{MHz}, \mathrm{CDCl}_{3}\right) \delta(\mathrm{ppm}) 163.4(\mathrm{dd}, J=12.7,248.6 \mathrm{~Hz}), 157.7$, 
$146.7(\mathrm{q}, J=4.1 \mathrm{~Hz}), 141.0(\mathrm{t}, J=9.4 \mathrm{~Hz}), 134.2(\mathrm{q}, J=3.5 \mathrm{~Hz}), 125.9(\mathrm{q}, J=33.3 \mathrm{~Hz})$, $123.5(\mathrm{q}, J=272.3 \mathrm{~Hz}), 119.8,110.1(\mathrm{~d}, J=26.7 \mathrm{~Hz}), 105.2(\mathrm{t}, J=25.5 \mathrm{~Hz})$. Elemental analysis: calcd (\%) for $\mathrm{C}_{12} \mathrm{H}_{6} \mathrm{~F}_{5} \mathrm{~N}$ (259.18): C 55.61, H 2.33, N 5.40; found: C 55.68, H 2.49, N 5.68 .

\section{Ethyl 3',5'-difluoro-3'-(5-(trifluoromethyl)pyridin-2-yl)-[1,1'-biphenyl]-4-carboxylate}

(6): To a $15 \mathrm{~mL}$ oven dried Schlenk tube, 2-(3,5-difluorophenyl)-5-(trifluoromethyl)pyridine (5) $(259 \mathrm{mg}, 1.00 \mathrm{mmol}$ ), ethyl 4-bromobenzoate (343 mg, $1.5 \mathrm{mmol}$ ), PivOK (280 mg, 2 mmol), DMA (3 mL) and $\mathrm{PdCl}\left(\mathrm{C}_{3} \mathrm{H}_{5}\right)(\mathrm{dppb})(30 \mathrm{mg}, 0.05 \mathrm{mmol}, 5 \mathrm{~mol} \%)$ were successively added. The reaction mixture was evacuated by vacuum-argon cycles ( 5 times) and stirred at $150{ }^{\circ} \mathrm{C}$ (oil bath temperature) for 48 hours. After cooling the reaction at room temperature and concentration, the crude mixture was purified by flash chromatography on silica gel (EtOAc-Heptane, 70:30) to afford the desired compound 6 (293 mg, 72\%). ${ }^{1} \mathrm{H}$ NMR (400 $\left.\mathrm{MHz}, \mathrm{CDCl}_{3}\right) \delta(\mathrm{ppm}) 8.97(\mathrm{~s}, 1 \mathrm{H}), 8.16(\mathrm{~d}, J=8.0 \mathrm{~Hz}, 2 \mathrm{H}), 8.03(\mathrm{~d}, J=8.4 \mathrm{~Hz}, 1 \mathrm{H}), 7.85$ $(\mathrm{d}, J=8.3 \mathrm{~Hz}, 1 \mathrm{H}), 7.75(\mathrm{~d}, J=8.4 \mathrm{~Hz}, 2 \mathrm{H}), 7.61(\mathrm{~d}, J=8.0 \mathrm{~Hz}, 2 \mathrm{H}), 4.43(\mathrm{q}, J=7.2 \mathrm{~Hz}$, 2H), $1.43(\mathrm{t}, J=7.1 \mathrm{~Hz}, 3 \mathrm{H}) .{ }^{19} \mathrm{~F}\left\{{ }^{1} \mathrm{H}\right\} \mathrm{NMR}\left(376 \mathrm{MHz}, \mathrm{CDCl}_{3}\right) \delta(\mathrm{ppm})-62.4(\mathrm{~s}),-112.9$ (s). ${ }^{13} \mathrm{C}\left\{{ }^{1} \mathrm{H}\right\}$ NMR (100 MHz, $\left.\mathrm{CDCl}_{3}\right) \delta(\mathrm{ppm}) 166.1,160.3(\mathrm{dd}, J=7.4,249.7 \mathrm{~Hz}), 157.4,146.8$ $(\mathrm{q}, J=4.0 \mathrm{~Hz}), 139.6(\mathrm{t}, J=9.8 \mathrm{~Hz}), 134.3(\mathrm{q}, J=3.5 \mathrm{~Hz}), 133.2,130.5,130.3,129.5,125.9$ $(\mathrm{q}, J=33.2 \mathrm{~Hz}), 123.5(\mathrm{q}, J=271.5 \mathrm{~Hz}), 119.8,118.9(\mathrm{t}, J=18.6 \mathrm{~Hz}), 110.5(\mathrm{~d}, J=27.9$ $\mathrm{Hz}), 61.1,14.3$. Elemental analysis: calcd (\%) for $\mathrm{C}_{21} \mathrm{H}_{14} \mathrm{~F}_{5} \mathrm{NO}_{2}$ (407.34): C 61.92, $\mathrm{H} \mathrm{3.46,} \mathrm{N}$ 3.44; found: C 62.12, H 3.23, N 3.56.

\section{Iridium(III) bis[2-(2,4-difluorophenyl)-5-(trifluoromethyl)pyridinato-N, $\mathrm{C}^{2}$ ]picolinate} (F1): $\quad \mathrm{IrCl}_{3} .6 \mathrm{H}_{2} \mathrm{O} \quad(75 \mathrm{mg}, \quad 0.25 \mathrm{mmol}, \quad 1.0 \quad$ eq. $)$ and 2-(2,4-difluorophenyl)-5(trifluoromethyl)pyridine (1) (142 mg, $0.55 \mathrm{mmol}, 2.2$ eq.) were suspended in a mixture of 2ethoxyethanol/water $(5 \mathrm{~mL}, 3 / 1)$. The mixture was heated and kept at $125{ }^{\circ} \mathrm{C}$ under stirring. After $24 \mathrm{~h}$, it was allowed to cool to room temperature and the solvent was removed under vacuo to give the intermediate $\left[\operatorname{Ir}\left(\mathrm{C}^{\wedge} \mathrm{N}\right)_{2} \mathrm{Cl}\right]_{2}$ dimer complex, which was directly engaged in the next step without further purification. This complex and picolinic acid (104 mg, 0.75 mmol, 6 eq.) were dissolved in 2-ethoxyethanol $(8 \mathrm{~mL})$, and $\mathrm{Na}_{2} \mathrm{CO}_{3}(159 \mathrm{mg}, 1.5 \mathrm{mmol}, 6$ eq.) was added. The solution was heated at $125^{\circ} \mathrm{C}$ for $24 \mathrm{~h}$. The solution was allowed to cool to room temperature. After concentration, the residue was purified by flash chromatography 
on silica gel $\left(\mathrm{CH}_{2} \mathrm{Cl}_{2}\right.$ - EtOAc, 75:25) to afford the desired complex F1 (135 mg, 65\%). ${ }^{1} \mathrm{H}$ NMR (400 MHz, $\left.\mathrm{CDCl}_{3}\right) \delta(\mathrm{ppm}) 9.02(\mathrm{~s}, 1 \mathrm{H}), 8.47-8.36(\mathrm{~m}, 3 \mathrm{H}), 8.12-7.96(\mathrm{~m}, 3 \mathrm{H})$, $7.79(\mathrm{~d}, J=5.3 \mathrm{~Hz}, 1 \mathrm{H}), 7.54(\mathrm{t}, J=6.6 \mathrm{~Hz}, 1 \mathrm{H}), 7.50(\mathrm{~s}, 1 \mathrm{H}), 6.56(\mathrm{t}, J=10.7 \mathrm{~Hz}, 1 \mathrm{H}), 6.46$ $(\mathrm{t}, J=10.8 \mathrm{~Hz}, 1 \mathrm{H}), 5.82(\mathrm{~d}, J=8.3 \mathrm{~Hz}, 1 \mathrm{H}), 5.55(\mathrm{~d}, J=8.4 \mathrm{~Hz}, 1 \mathrm{H}) .{ }^{19} \mathrm{~F}\left\{{ }^{1} \mathrm{H}\right\} \mathrm{NMR}(376$ $\left.\mathrm{MHz}, \mathrm{CDCl}_{3}\right) \delta(\mathrm{ppm})-62.1,-62.8,-103.4(\mathrm{~d}, J=12.3 \mathrm{~Hz}),-104.3(\mathrm{~d}, J=11.7 \mathrm{~Hz})$, -

107.30(d, $J=11.9 \mathrm{~Hz}),-108.1(\mathrm{~d}, J=11.6 \mathrm{~Hz}) .{ }^{13} \mathrm{C}\left\{{ }^{1} \mathrm{H}\right\} \mathrm{NMR}\left(100 \mathrm{MHz}, \mathrm{CDCl}_{3}\right) \delta(\mathrm{ppm})$ 172.1, 169.1 (d, $J=7.0 \mathrm{~Hz}), 167.7$ (d, $J=6.9 \mathrm{~Hz}), 164.5$ (dd, $J=12.9,260.0 \mathrm{~Hz}), 164.1$ (dd, $J=12.6,259.3 \mathrm{~Hz}), 162.4(\mathrm{dd}, J=10.5,261.9 \mathrm{~Hz}), 162.2(\mathrm{dd}, J=10.2,262.0 \mathrm{~Hz}), 153.5$ (d, $J=7.2 \mathrm{~Hz}), 152.4(\mathrm{~d}, J=7.3 \mathrm{~Hz}), 151.4,148.3,145.6(\mathrm{q}, J=4.3 \mathrm{~Hz}), 144.5(\mathrm{q}, J=4.8 \mathrm{~Hz})$, 139.2, 135.8 - $135.5(\mathrm{~m}), 129.0(\mathrm{~d}, J=3.6 \mathrm{~Hz}), 126.9-126.7(\mathrm{~m}), 125.5(\mathrm{q}, J=34.9 \mathrm{~Hz})$, $125.1(\mathrm{q}, J=34.7 \mathrm{~Hz}), 123.0(\mathrm{~d}, J=21.1 \mathrm{~Hz}), 122.5(\mathrm{~d}, J=19.9 \mathrm{~Hz}), 122.1(\mathrm{q}, J=271.4$ Hz), 121.9 (q, $J=270.4 \mathrm{~Hz}), 114.9$ (dd, $J=2.7,17.4 \mathrm{~Hz}), 114.6(\mathrm{dd}, J=2.7,17.7 \mathrm{~Hz}), 98.9$ $(\mathrm{d}, J=27.3 \mathrm{~Hz}), 98.4(\mathrm{~d}, J=27.1 \mathrm{~Hz})$. MALDI HRMS for $\mathrm{C}_{30} \mathrm{H}_{15} \mathrm{~N}_{3} \mathrm{~F}_{10}{ }^{193} \mathrm{Ir}[\mathrm{M}+\mathrm{H}]^{+}$: found found 832.0062, calcd 832.066. Elemental analysis: calcd (\%) for $\mathrm{C}_{30} \mathrm{H}_{14} \mathrm{~N}_{3} \mathrm{~F}_{10} \mathrm{Ir}$ (831.05): C 43.38, H 1.70, N 5.06; found: C 43.24, H 1.45, N 5.02

\section{Iridium(III)}

bis[2-(4'-cyano-2,6-difluoro-[1,1'-biphenyl]-3-yl)-5-

(trifluoromethyl)pyridinato-N, $\mathbf{C}^{2}$ ']picolinate (F2): $\mathrm{IrCl}_{3} \cdot 6 \mathrm{H}_{2} \mathrm{O}(75 \mathrm{mg}, 0.25 \mathrm{mmol}, 1.0$ eq.) and 2',6'-difluoro-3'-(5-(trifluoromethyl)pyridin-2-yl)-[1,1'-biphenyl]-4-carbonitrile (2) (198 $\mathrm{mg}, 0.55 \mathrm{mmol}, 2.2$ eq.) were suspended in a mixture of 2-ethoxyethanol/water $(5 \mathrm{~mL}, 3 / 1)$. The mixture was heated and kept at $125^{\circ} \mathrm{C}$ under stirring. After $24 \mathrm{~h}$, it was allowed to cool to room temperature and the solvent was removed under vacuo to give the intermediate $\left[\operatorname{Ir}\left(\mathrm{C}^{\wedge} \mathrm{N}\right)_{2} \mathrm{Cl}\right]_{2}$ dimer complex, which was directly engaged in the next step without further purification. This complex and picolinic acid (104 mg, $0.75 \mathrm{mmol}, 6$ eq.) were dissolved in 2-ethoxyethanol ( $8 \mathrm{~mL}$ ), and $\mathrm{Na}_{2} \mathrm{CO}_{3}$ (159 mg, $1.5 \mathrm{mmol}, 6$ eq.) was added. The solution was heated at $125^{\circ} \mathrm{C}$ for $24 \mathrm{~h}$. The solution was allowed to cool to room temperature. After concentration, the residue was purified by flash chromatography on silica gel $\left(\mathrm{CH}_{2} \mathrm{Cl}_{2}\right.$ EtOAc, 75:25) to afford the desired complex F2 (176 mg, 68\%). ${ }^{1} \mathrm{H} \mathrm{NMR} \mathrm{(400} \mathrm{MHz,}$ $\left.\mathrm{CDCl}_{3}\right) \delta(\mathrm{ppm}) 9.09(\mathrm{~s}, 1 \mathrm{H}), 8.53-8.42(\mathrm{~m}, 3 \mathrm{H}), 8.16-8.07(\mathrm{~m}, 3 \mathrm{H}), 7.92(\mathrm{~d}, J=5.3 \mathrm{~Hz}$, 1H), $7.81-7.69$ (m, 3H), $7.68-7.57$ (m, 4H), $7.56-7.46(\mathrm{~m}, 3 \mathrm{H}), 6.06$ (d, J=9.2 Hz, 1H), $5.75(\mathrm{~d}, J=9.2 \mathrm{~Hz}, 1 \mathrm{H}) .{ }^{19} \mathrm{~F}\left\{{ }^{1} \mathrm{H}\right\} \mathrm{NMR}\left(376 \mathrm{MHz}, \mathrm{CDCl}_{3}\right) \delta(\mathrm{ppm})-62.1(\mathrm{~s}),-62.8(\mathrm{~s}),-$ $107.6(\mathrm{~d}, J=11.1 \mathrm{~Hz}),-108.4(\mathrm{~d}, J=10.9 \mathrm{~Hz}),-112.5(\mathrm{~d}, J=11.1 \mathrm{~Hz}),-113.2$ (d, $J=11.1$ 
$\mathrm{Hz}) .{ }^{13} \mathrm{C}\left\{{ }^{1} \mathrm{H}\right\} \mathrm{NMR}\left(100 \mathrm{MHz}, \mathrm{CDCl}_{3}\right) \delta(\mathrm{ppm}) 172.0,168.9(\mathrm{~d}, J=6.9 \mathrm{~Hz}), 167.7,167.6(\mathrm{~d}$, $J=7.2 \mathrm{~Hz}), 160.9(\mathrm{dd}, J=7.0,261.6 \mathrm{~Hz}), 160.5(\mathrm{dd}, J=6.8,260.9 \mathrm{~Hz}), 158.6$ (dd, $J=7.6$, $263.5 \mathrm{~Hz}), 158.5$ (dd, $J=7.4,262.7 \mathrm{~Hz}), 153.3(\mathrm{~d}, J=7.6 \mathrm{~Hz}), 152.5$ (d, $J=7.7 \mathrm{~Hz}), 151.3$, 148.4, 145.8 (q, $J=4.3 \mathrm{~Hz}), 144.7$ (q, $J=4.5 \mathrm{~Hz}), 139.6,136.1,134.3$ (d, $J=22.9 \mathrm{~Hz})$, 132.3, 132.0 (d, $J=7.3 \mathrm{~Hz}), 131.0$ (d, $J=4.6 \mathrm{~Hz}), 130.9,129.2$ (d, $J=11.7 \mathrm{~Hz}), 128.8,127.6$ - $127.4(\mathrm{~m}), 126.1$ (q, $J=35.6 \mathrm{~Hz}), 125.7$ (q, $J=36.0 \mathrm{~Hz}), 123.4(\mathrm{~d}, J=22.9 \mathrm{~Hz}), 122.9$ (d, $J$ $=21.3 \mathrm{~Hz}), 121.9(\mathrm{q}, J=271.4 \mathrm{~Hz}), 121.8(\mathrm{q}, J=271.4 \mathrm{~Hz}), 118.6(\mathrm{~d}, J=9.3 \mathrm{~Hz}), 115.6(\mathrm{~d}$, $J=18.7 \mathrm{~Hz}), 115.2(\mathrm{~d}, J=19.3 \mathrm{~Hz}), 111.8,111.7,111.5(\mathrm{t}, J=19.7 \mathrm{~Hz}), 111.0(\mathrm{t}, J=19.3$ $\mathrm{Hz}$ ). MALDI HRMS for $\mathrm{C}_{44} \mathrm{H}_{21} \mathrm{~N}_{5} \mathrm{O}_{2} \mathrm{~F}_{10}{ }^{193} \mathrm{Ir}[\mathrm{M}+\mathrm{H}]^{+}$: found 1034.1160, calcd 1034.121. Elemental analysis: calcd (\%) for $\mathrm{C}_{44} \mathrm{H}_{20} \mathrm{~N}_{5} \mathrm{O}_{2} \mathrm{~F}_{10} \mathrm{Ir}$ (1032.87): C 51.17, H 1.95, N 6.78; found: C 51.08, H 2.12, N 6.98

Iridium(III) bis[2-((4'-(ethoxycarbonyl)-2,6-difluoro-[1,1'-biphenyl] 3-yl)-5(trifluoromethyl)pyridinato- $\mathbf{N}, \mathbf{C}^{2}$ ']picolinate (F3): $\mathrm{IrCl}_{3} \cdot 6 \mathrm{H}_{2} \mathrm{O}(75 \mathrm{mg}, 0.25 \mathrm{mmol}, 1.0 \mathrm{eq}$.) and ethyl 2',6'-difluoro-3'-(5-(trifluoromethyl)pyridin-2-yl)-[1,1'-biphenyl]-4-carboxylate (3) (224 mg, $0.55 \mathrm{mmol}, 2.2$ eq.) were suspended in a mixture of 2-ethoxyethanol/water $(5 \mathrm{~mL}$, 3/1). The mixture was heated and kept at $125^{\circ} \mathrm{C}$ under stirring. After $24 \mathrm{~h}$, it was allowed to cool to room temperature and the solvent was removed under vacuo to give the dime $\mathrm{r}\left[\operatorname{Ir}\left(\mathrm{C}^{\wedge} \mathrm{N}\right)_{2} \mathrm{Cl}\right]_{2}$, which was directly engaged in the next step without further purification. This complex and picolinic acid (104 mg, $0.75 \mathrm{mmol}, 6$ eq.) were dissolved in 2-ethoxyethanol (8 $\mathrm{mL}$ ), and $\mathrm{Na}_{2} \mathrm{CO}_{3}\left(159 \mathrm{mg}, 1.5 \mathrm{mmol}, 6\right.$ eq.) was added. The solution was heated at $125^{\circ} \mathrm{C}$ for $24 \mathrm{~h}$. The solution was allowed to cool to room temperature. After concentration, the residue was purified by flash chromatography on silica gel $\left(\mathrm{CH}_{2} \mathrm{Cl}_{2}-\mathrm{EtOAc}, 75: 25\right)$ to afford the desired complex F3 (175 mg, 62\%). ${ }^{1} \mathrm{H}$ NMR (400 MHz, Acetone- $\left.d_{6}\right) \delta(\mathrm{ppm}) 9.13(\mathrm{~s}$, $1 \mathrm{H}), 8.63(\mathrm{t}, J=7.3 \mathrm{~Hz}, 2 \mathrm{H}), 8.44(\mathrm{t}, J=9.4 \mathrm{~Hz}, 2 \mathrm{H}), 8.32-8.22(\mathrm{~m}, 2 \mathrm{H}), 8.16(\mathrm{~d}, J=5.3$ $\mathrm{Hz}, 1 \mathrm{H}), 8.14-8.08(\mathrm{~m}, 4 \mathrm{H}), 7.90(\mathrm{~s}, 1 \mathrm{H}), 7.78-7.71(\mathrm{~m}, 1 \mathrm{H}), 7.68-7.60(\mathrm{~m}, 4 \mathrm{H}), 6.29$ (d, $J=9.6 \mathrm{~Hz}, 1 \mathrm{H}), 5.94(\mathrm{~d}, J=9.5 \mathrm{~Hz}, 1 \mathrm{H}), 4.40(\mathrm{q}, J=7.3,8.3 \mathrm{~Hz}, 2 \mathrm{H}), 4.39$ (q, $J=7.3,8.3$ $\mathrm{Hz}, 2 \mathrm{H}), 1.40(\mathrm{t}, J=7.1 \mathrm{~Hz}, 3 \mathrm{H}), 1.39(\mathrm{t}, J=7.1 \mathrm{~Hz}, 3 \mathrm{H}) .{ }^{19} \mathrm{~F}\left\{{ }^{1} \mathrm{H}\right\}$ NMR $(376 \mathrm{MHz}$, Acetone- $\left.d_{6}\right) \delta(\mathrm{ppm})-63.2(\mathrm{~d}, J=154.6 \mathrm{~Hz}),-110.0(\mathrm{~d}, J=12.1 \mathrm{~Hz}),-110.6(\mathrm{~d}, J=11.9 \mathrm{~Hz})$, $-113.7(\mathrm{~d}, J=12.1 \mathrm{~Hz}),-114.1(\mathrm{~d}, J=12.0 \mathrm{~Hz}) .{ }^{13} \mathrm{C}\left\{{ }^{1} \mathrm{H}\right\} \mathrm{NMR}\left(100 \mathrm{MHz}\right.$, Acetone- $\left.d_{6}\right) \delta$ (ppm) 172.0, 168.6 (d, $J=7.1 \mathrm{~Hz}), 168.0(\mathrm{~d}, J=7.2 \mathrm{~Hz}), 165.6,161.0$ (dd, $J=7.4,258.5$ Hz), 160.5 (dd, $J=7.4,257.9 \mathrm{~Hz}), 158.9$ (dd, $J=7.4,261.8 \mathrm{~Hz}$ ), 158.5 (dd, $J=7.4,261.9$ 
$\mathrm{Hz}), 154.5$ (d, $J=7.6 \mathrm{~Hz}), 152.7(\mathrm{~d}, J=7.8 \mathrm{~Hz}), 151.4,149.4,145.5$ (q, $J=4.5 \mathrm{~Hz}), 145.2$ (q, $J=4.1 \mathrm{~Hz}), 139.8,136.7,134.4,130.5,130.5(\mathrm{~m}), 130.0,129.4,129.1(\mathrm{~m}), 128.3,127.7$ (m), $125.3(\mathrm{~d}, J=16.7 \mathrm{~Hz}), 124.9(\mathrm{~d}, J=16.2 \mathrm{~Hz}), 124.0-123.2(\mathrm{~m}), 121.2(\mathrm{~d}, J=23.9 \mathrm{~Hz})$, $115.7(\mathrm{~d}, J=19.3 \mathrm{~Hz}), 114.8(\mathrm{~d}, J=18.7 \mathrm{~Hz}), 112.0-111.1(\mathrm{~m}), 60.7,13.7$. MALDI HRMS for $\mathrm{C}_{48} \mathrm{H}_{31} \mathrm{~N}_{3} \mathrm{O}_{6} \mathrm{~F}_{10}{ }^{193} \operatorname{Ir}[\mathrm{M}+\mathrm{H}]^{+}$: found 1128.1677, calcd 1128.170. Elemental analysis: calcd (\%) for $\mathrm{C}_{48} \mathrm{H}_{30} \mathrm{~N}_{3} \mathrm{O}_{6} \mathrm{~F}_{10} \operatorname{Ir}$ (1126.28): C 51.16, H 2.68, N 3.73; found: C 51.21, H 2.89, N 3.23.

\section{Iridium(III)}

bis[2-(4'-acetyl-2,6-difluoro-[1,1'-biphenyl]-3-yl)-5-

(trifluoromethyl)pyridinato- $\mathbf{N}, \mathbf{C}^{2}$ ']picolinate (F4): $\mathrm{IrCl}_{3} \cdot 6 \mathrm{H}_{2} \mathrm{O}(75 \mathrm{mg}, 0.25 \mathrm{mmol}, 1.0$ eq.) and 1-(2',6'-difluoro-3'-(5-(trifluoromethyl)pyridin-2-yl)-[1,1'-biphenyl]-4-yl)ethan-1-one (4) (153 mg, $0.55 \mathrm{mmol}, 2.2$ eq.) were suspended in a mixture of 2-ethoxyethanol/water $(5 \mathrm{~mL}$, 3/1). The mixture was heated and kept at $125^{\circ} \mathrm{C}$ under stirring. After $24 \mathrm{~h}$, it was allowed to cool to room temperature and the solvent was removed under vacuo to give the intermediate $\left[\operatorname{Ir}\left(\mathrm{C}^{\wedge} \mathrm{N}\right)_{2} \mathrm{Cl}\right]_{2}$ dimer complex, which was directly engaged in the next step without further purification. This complex and picolinic acid (104 mg, $0.75 \mathrm{mmol}, 6$ eq.) were dissolved in 2-ethoxyethanol ( $8 \mathrm{~mL}$ ), and $\mathrm{Na}_{2} \mathrm{CO}_{3}$ (159 mg, $1.5 \mathrm{mmol}, 6$ eq.) was added. The solution was heated at $125^{\circ} \mathrm{C}$ for $24 \mathrm{~h}$. The solution was allowed to cool to room temperature. After concentration, the residue was purified by flash chromatography on silica gel $\left(\mathrm{CH}_{2} \mathrm{Cl}_{2}-\right.$ EtOAc, 75:25) to afford the desired complex F4 (160 mg, 60\%). ${ }^{1} \mathrm{H} \mathrm{NMR} \mathrm{(400} \mathrm{MHz,}$ $\left.\mathrm{CDCl}_{3}\right) \delta(\mathrm{ppm}) 9.10(\mathrm{~s}, 1 \mathrm{H}), 8.55-8.34(\mathrm{~m}, 3 \mathrm{H}), 8.12-7.94(\mathrm{~m}, 7 \mathrm{H}), 7.94(\mathrm{~s}, 1 \mathrm{H}), 7.65-$ $7.54(\mathrm{~m}, 4 \mathrm{H}), 7.50(\mathrm{~d}, J=8.0 \mathrm{~Hz}, 2 \mathrm{H}), 6.06(\mathrm{~d}, J=9.2 \mathrm{~Hz}, 1 \mathrm{H}), 5.75(\mathrm{~d}, J=9.2 \mathrm{~Hz}, 1 \mathrm{H})$, $2.65(\mathrm{~s}, 3 \mathrm{H}), 2.63(\mathrm{~s}, 3 \mathrm{H}) .{ }^{19} \mathrm{~F}\left\{{ }^{1} \mathrm{H}\right\}$ NMR $\left(376 \mathrm{MHz}, \mathrm{CDCl}_{3}\right) \delta(\mathrm{ppm})-62.2(\mathrm{~s}),-62.8(\mathrm{~s}),-$ $107.2(\mathrm{~d}, J=11.4 \mathrm{~Hz}),-108.1(\mathrm{~d}, J=11.3 \mathrm{~Hz}),-112.2(\mathrm{~d}, J=11.7 \mathrm{~Hz}),-112.9(\mathrm{~d}, J=11.7$ $\mathrm{Hz}) .{ }^{13} \mathrm{C}\left\{{ }^{1} \mathrm{H}\right\} \mathrm{NMR}\left(100 \mathrm{MHz}, \mathrm{CDCl}_{3}\right) \delta(\mathrm{ppm})$ 197.6, 197.5, 172.0, $169.1(\mathrm{~d}, J=7.0 \mathrm{~Hz})$, $167.8(\mathrm{~d}, J=6.7 \mathrm{~Hz}), 161.2$ (dd, $J=7.1,261.3 \mathrm{~Hz}), 160.8(\mathrm{dd}, J=6.7,260.6 \mathrm{~Hz}), 158.9$ (dd, $J=10.0,264.9 \mathrm{~Hz}), 158.8(\mathrm{dd}, J=7.5,262.6 \mathrm{~Hz}), 152.6(\mathrm{~d}, J=7.6 \mathrm{~Hz}), 151.7(\mathrm{~d}, J=7.4$ Hz), 151.4, 148.4, 145.8 (q, $J=4.6 \mathrm{~Hz}), 144.7$ (q, $J=4.9 \mathrm{~Hz}), 139.4,136.4(\mathrm{~d}, J=10.8 \mathrm{~Hz})$, 135.9, $134.3(\mathrm{~d}, J=25.8 \mathrm{~Hz}), 130.5,129.1(\mathrm{~d}, J=10.9 \mathrm{~Hz}), 128.2(\mathrm{~d}, J=7.2 \mathrm{~Hz}), 127.4(\mathrm{~m})$, $125.9(\mathrm{q}, J=36.7 \mathrm{~Hz}), 125.5(\mathrm{~d}, J=35.8 \mathrm{~Hz}), 123.3(\mathrm{~d}, J=3.9 \mathrm{~Hz}), 122.8(\mathrm{~d}, J=21.3 \mathrm{~Hz})$, $122.0(\mathrm{q}, J=272.1 \mathrm{~Hz}), 121.9(\mathrm{q}, J=272.1 \mathrm{~Hz}), 115.5(\mathrm{~d}, J=18.9 \mathrm{~Hz}), 115.1(\mathrm{~d}, J=19.1$ $\mathrm{Hz}), 112.2(\mathrm{t}, J=19.9 \mathrm{~Hz}), 111.7(\mathrm{t}, J=19.7 \mathrm{~Hz}), 26.6$. MALDI HRMS for 
$\mathrm{C}_{46} \mathrm{H}_{27} \mathrm{~N}_{3} \mathrm{O}_{4} \mathrm{~F}_{10}{ }^{193} \operatorname{Ir}[\mathrm{M}+\mathrm{H}]^{+}$: found 1068.1466, calcd 1068.145. Elemental analysis: calcd (\%) for $\mathrm{C}_{46} \mathrm{H}_{26} \mathrm{~N}_{3} \mathrm{O}_{4} \mathrm{~F}_{10} \operatorname{Ir}(1066.93)$ : C 51.78, H 2.46, N 3.94 found: C 51.88, H 2.43, N 4.12.

\section{Iridium(III) bis[2-(3,5-difluorophenyl)-5-(trifluoromethyl)pyridinato-N,C $\left.{ }^{2}\right]$ picolinate} (F5): $\quad \mathrm{IrCl}_{3} \cdot 6 \mathrm{H}_{2} \mathrm{O} \quad(75 \mathrm{mg}, \quad 0.25 \mathrm{mmol}, \quad 1.0$ eq.) and 2-(3,5-difluorophenyl)-5(trifluoromethyl)pyridine (5) (142 $\mathrm{mg}, 0.55 \mathrm{mmol}, 2.2 \mathrm{eq}$.) were suspended in a mixture of 2ethoxyethanol/water $(5 \mathrm{~mL}, 3 / 1)$. The mixture was heated and kept at $125{ }^{\circ} \mathrm{C}$ under stirring. After $24 \mathrm{~h}$, it was allowed to cool to room temperature and the solvent was removed under vacuo to give the intermediate $\left[\operatorname{Ir}\left(\mathrm{C}^{\wedge} \mathrm{N}\right)_{2} \mathrm{Cl}\right]_{2}$ dimer complex, which was directly engaged in the next step without further purification. This complex and picolinic acid (104 mg, 0.75 mmol, 6 eq.) were dissolved in 2-ethoxyethanol $(8 \mathrm{~mL})$, and $\mathrm{Na}_{2} \mathrm{CO}_{3}(159 \mathrm{mg}, 1.5 \mathrm{mmol}, 6$ eq.) was added. The solution was heated at $125^{\circ} \mathrm{C}$ for $24 \mathrm{~h}$. The solution was allowed to cool to room temperature. After concentration, the residue was purified by flash chromatography on silica gel $\left(\mathrm{CH}_{2} \mathrm{Cl}_{2}\right.$ - EtOAc, 75:25) to afford the desired complex $\mathbf{F 5}(141 \mathrm{mg}, 68 \%)$. ${ }^{1} \mathrm{H}$ NMR (400 MHz, Acetone- $d_{6}$ ) $\delta(\mathrm{ppm}) 9.09$ (s, 1H), 8.49 (t, $\left.J=7.8 \mathrm{~Hz}, 2 \mathrm{H}\right), 8.32$ (d, $J=8.6$ $\mathrm{Hz}, 2 \mathrm{H}), 8.28-8.19(\mathrm{~m}, 2 \mathrm{H}), 8.00(\mathrm{~d}, J=5.3 \mathrm{~Hz}, 1 \mathrm{H}), 7.83$ (dd, $J=2.5,9.4 \mathrm{~Hz}, 1 \mathrm{H}), 7.79-$ $7.66(\mathrm{~m}, 3 \mathrm{H}), 6.60(\mathrm{td}, J=2.4,9.3 \mathrm{~Hz}, 1 \mathrm{H}), 6.49(\mathrm{td}, J=2.4,9.5 \mathrm{~Hz}, 1 \mathrm{H}) .{ }^{19} \mathrm{~F}\left\{{ }^{1} \mathrm{H}\right\} \mathrm{NMR}$ $\left(376 \mathrm{MHz}\right.$, Acetone- $\left.d_{6}\right) \delta(\mathrm{ppm})-63.0,-63.5,-102.2(\mathrm{~d}, J=5.8 \mathrm{~Hz}),-103.9$ (d, $\left.J=5.8 \mathrm{~Hz}\right),-$ $120.6(\mathrm{~d}, J=6.0 \mathrm{~Hz}),-120.7(\mathrm{~d}, J=5.8 \mathrm{~Hz}) .{ }^{13} \mathrm{C}\left\{{ }^{1} \mathrm{H}\right\}$ NMR $\left(100 \mathrm{MHz}\right.$, Acetone- $\left.d_{6}\right) \delta(\mathrm{ppm})$ 171.8, $171.4(\mathrm{~d}, J=4.3 \mathrm{~Hz}), 170.9$ (d, $J=3.0 \mathrm{~Hz}), 169.1$ (dd, $J=11.2,238.3 \mathrm{~Hz}), 168.8$ (dd, $J=11.2,245.1 \mathrm{~Hz}), 159.9(\mathrm{dd}, J=12.5,238.7 \mathrm{~Hz}), 159.7(\mathrm{dd}, J=12.1,238.5 \mathrm{~Hz}), 151.6$, 149.2, 147.4 - 146.8 (m), 145.8 - 145.2 (m), 139.7, 135.7 - 135.5 (m), 129.5, 128.4, 125.1 (d, $J=8.9 \mathrm{~Hz}), 124.8(\mathrm{~d}, J=9.1 \mathrm{~Hz}), 127.9,124.1(\mathrm{q}, J=272.1 \mathrm{~Hz}), 122.5(\mathrm{q}, J=271.8$ $=\mathrm{Hz}), 122.4,122.1,120.6,120.3,109.1$ (dd, $J=3.8,22.2 \mathrm{~Hz}), 108.7$ (dd, $J=3.8,22.0 \mathrm{~Hz}$ ), $105.6(\mathrm{dd}, J=24.9,62.0 \mathrm{~Hz}), 105.6(\mathrm{dd}, J=2.2,24.8 \mathrm{~Hz}) . \quad$ MALDI HRMS for $\mathrm{C}_{30} \mathrm{H}_{15} \mathrm{~N}_{3} \mathrm{~F}_{10}{ }^{193} \operatorname{Ir}[\mathrm{M}+\mathrm{H}]^{+}$: found 832.0062, calcd 832.066. Elemental analysis: calcd (\%) for $\mathrm{C}_{30} \mathrm{H}_{14} \mathrm{~N}_{3} \mathrm{~F}_{10} \mathrm{Ir}$ (831.05): C 43.38, H 1.70, N 5.06; found: C 43.65, H 1.67, N 5.26

Iridium(III) bis[2-((4'-(ethoxycarbonyl)-3,5-difluoro-[1,1'-biphenyl]-4-yl)-5(trifluoromethyl)pyridinato-N, $\mathbf{C}^{2}$ ']picolinate (F6): $\mathrm{IrCl}_{3} \cdot 6 \mathrm{H}_{2} \mathrm{O}(75 \mathrm{mg}, 0.25 \mathrm{mmol}, 1.0$ eq.) and ethyl 3',5'-difluoro-3'-(5-(trifluoromethyl)pyridin-2-yl)-[1,1'-biphenyl]-4-carboxylate (6) (224 mg, $0.55 \mathrm{mmol}, 2.2$ eq.) were suspended in a mixture of 2-ethoxyethanol/water $(5 \mathrm{~mL}$, 
3/1). The mixture was heated and kept at $125^{\circ} \mathrm{C}$ under stirring. After $24 \mathrm{~h}$, it was allowed to cool to room temperature and the solvent was removed under vacuo to give the intermediate $\left[\operatorname{Ir}\left(\mathrm{C}^{\wedge} \mathrm{N}\right)_{2} \mathrm{Cl}\right]_{2}$ dimer complex, which was directly engaged in the next step without further purification. This complex and picolinic acid (104 mg, $0.75 \mathrm{mmol}, 6$ eq.) were dissolved in 2-ethoxyethanol ( $8 \mathrm{~mL}$ ), and $\mathrm{Na}_{2} \mathrm{CO}_{3}$ (159 mg, $1.5 \mathrm{mmol}, 6$ eq.) was added. The solution was heated at $125^{\circ} \mathrm{C}$ for $24 \mathrm{~h}$. The solution was allowed to cool to room temperature. After concentration, the residue was purified by flash chromatography on silica gel $\left(\mathrm{CH}_{2} \mathrm{Cl}_{2}\right.$ EtOAc, 75:25) to afford the desired complex F6 (186 mg, 66\%). ${ }^{1} \mathrm{H} \mathrm{NMR}(400 \mathrm{MHz}$, $\left.\mathrm{CDCl}_{3}\right) \delta(\mathrm{ppm}) 9.11(\mathrm{~s}, 1 \mathrm{H}), 8.41(\mathrm{~d}, J=7.7 \mathrm{~Hz}, 1 \mathrm{H}), 8.10-8.06(\mathrm{~m}, 1 \mathrm{H}), 8.04(\mathrm{~d}, J=8.3$ $\mathrm{Hz}, 2 \mathrm{H}), 7.98$ (d, $J=8.3 \mathrm{~Hz}, 3 \mathrm{H}), 7.95-7.86(\mathrm{~m}, 4 \mathrm{H}), 7.57$ (t, $J=6.5 \mathrm{~Hz}, 1 \mathrm{H}), 7.51-7.40$ $(\mathrm{m}, 5 \mathrm{H}), 7.33(\mathrm{~d}, J=8.0 \mathrm{~Hz}, 2 \mathrm{H}), 4.46-4.31(\mathrm{~m}, 4 \mathrm{H}), 1.39(\mathrm{~s}, 6 \mathrm{H}) .{ }^{19} \mathrm{~F}\left\{{ }^{1} \mathrm{H}\right\}$ NMR $(376$ $\left.\mathrm{MHz}, \mathrm{CDCl}_{3}\right) \delta(\mathrm{ppm})-62.2,-62.8,-107.3(\mathrm{~d}, J=7.0 \mathrm{~Hz}),-121.9(\mathrm{~d}, J=6.3 \mathrm{~Hz}),-122.3(\mathrm{~d}, J$ $=6.9 \mathrm{~Hz}) \cdot{ }^{13} \mathrm{C}\left\{{ }^{1} \mathrm{H}\right\} \mathrm{NMR}\left(100 \mathrm{MHz}, \mathrm{CDCl}_{3}\right) \delta(\mathrm{ppm}) 172.6,170.1(\mathrm{~d}, J=4.3 \mathrm{~Hz}), 169.9(\mathrm{~d}$, $J=4.3 \mathrm{~Hz}), 166.2,166.1,165.5(\mathrm{dd}, J=5.9,240.5 \mathrm{~Hz}), 165.0(\mathrm{dd}, J=5.9,241.1 \mathrm{~Hz}), 157.1$ $(\mathrm{dd}, J=6.6,241.8 \mathrm{~Hz}), 156.7(\mathrm{dd}, J=6.5,242.4 \mathrm{~Hz}), 151.5,148.4,146.6-146.2(\mathrm{~m}), 145.7$ - 145.0 (m), 129.3, 135.4 - 134.8 (m), 134.5, 134.0, 130.4 (d, $J=11.5 \mathrm{~Hz}), 130.0$ (d, $J=30.7$ $\mathrm{Hz}), 129.2,129.1,125.8$ (d, $J=34.7 \mathrm{~Hz}), 125.4$ (d, $J=34.4 \mathrm{~Hz}), 123.1,133.8,122.1$ (q, $J=$ $271.6 \mathrm{~Hz}), 122.0(\mathrm{q}, J=271.6 \mathrm{~Hz}), 121.8,121.4,120.2-119.9(\mathrm{~m}), 119.8,119.1,108.8(\mathrm{t}, J$ $=23.7 \mathrm{~Hz}), 108.9(\mathrm{t}, J=23.7 \mathrm{~Hz}), 61.1,60.1,14.3,14.3$. MALDI HRMS for $\mathrm{C}_{48} \mathrm{H}_{31} \mathrm{~N}_{3} \mathrm{O}_{6} \mathrm{~F}_{10}{ }^{193} \operatorname{Ir}[\mathrm{M}+\mathrm{H}]^{+}$: found 1128.1677 , calcd 1128.168. Elemental analysis: calcd (\%) for $\mathrm{C}_{48} \mathrm{H}_{30} \mathrm{~N}_{3} \mathrm{O}_{6} \mathrm{~F}_{10} \mathrm{Ir}$ (1126.28): C 51.16, H 2.68, N 3.73; found: C 51.09, H 2.76, N 3.85.

\section{Iridium(III) bis[2-(2,4-difluorophenyl)-5-(trifluoromethyl)pyridinato-N,C $\left.{ }^{2}\right]-4,4$ '-} dimetyl-2,2'-bipyridine hexafluorophosphate (G1): $\operatorname{IrCl}_{3} .6 \mathrm{H}_{2} \mathrm{O}(75 \mathrm{mg}, 0.25 \mathrm{mmol}, 1.0$ equiv.) and 2-(2,4-difluorophenyl)-5-(trifluoromethyl)pyridine (1) (129 mg, $0.5 \mathrm{mmol}, 2$ eq.) were suspended in a mixture of 2-ethoxyethanol/water $(5 \mathrm{~mL}, 3 / 1)$. The mixture was heated and kept at $125^{\circ} \mathrm{C}$ under stirring. After $24 \mathrm{~h}$, it was allowed to cool to room temperature and the solvent was removed under vacuo to give the intermediate $\left[\operatorname{Ir}\left(\mathrm{C}^{\wedge} \mathrm{N}\right)_{2} \mathrm{Cl}\right]_{2}$ dimer complex, which was directly engaged in the next step without further purification. The crude mixture of $\left[\operatorname{Ir}\left(\mathrm{C}^{\wedge} \mathrm{N}\right)_{2} \mathrm{Cl}\right]_{2}$ (1.0 equiv.) was dissolved in $5 \mathrm{~mL}$ of $\mathrm{CH}_{2} \mathrm{Cl}_{2}$ before addition of 4,4'dimethyl-2,2'-bipyridine (69 mg, $0.375 \mathrm{mmol}, 1.5$ equiv.) and $\mathrm{AgPF}_{6}(95 \mathrm{mg}, 0.375 \mathrm{mmol}$, 1.5 equiv.). The resulting solution was stirred at RT over 16 hours away from light. After concentration, the crude mixture was purified by silica column chromatography to afford the 
desired complex G1 (192 mg, 74\%). ${ }^{1} \mathrm{H}$ NMR (400 MHz, Acetone- $\left.d_{6}\right) \delta(\mathrm{ppm}) 8.78$ (s, 2H), $8.63(\mathrm{dd}, J=2.7,8.8 \mathrm{~Hz}, 2 \mathrm{H}), 8.41(\mathrm{~d}, J=8.7 \mathrm{~Hz}, 2 \mathrm{H}), 8.11(\mathrm{~d}, J=5.6 \mathrm{~Hz}, 2 \mathrm{H}), 8.01(\mathrm{~s}, 2 \mathrm{H})$, $7.63(\mathrm{~d}, J=5.7 \mathrm{~Hz}, 2 \mathrm{H}), 6.83(\mathrm{ddd}, J=2.3,9.3,12.2 \mathrm{~Hz}, 2 \mathrm{H}), 5.97(\mathrm{dd}, J=2.3,8.5 \mathrm{~Hz}, 2 \mathrm{H})$, $2.65(\mathrm{~s}, 6 \mathrm{H}) .{ }^{19} \mathrm{~F}\left\{{ }^{1} \mathrm{H}\right\}$ NMR (376 MHz, Acetone- $\left.d_{6}\right) \delta(\mathrm{ppm})-63.4,-72.3(\mathrm{~d}, J=707.6 \mathrm{~Hz}),-$ $104.8(\mathrm{~d}, J=11.9 \mathrm{~Hz}),-108.0(\mathrm{~d}, J=12.8 \mathrm{~Hz}) .{ }^{13} \mathrm{C}\left\{{ }^{1} \mathrm{H}\right\}$ NMR $\left(100 \mathrm{MHz}\right.$, Acetone- $\left.d_{6}\right) \delta$ (ppm) $167.8(\mathrm{~d}, J=7.0 \mathrm{~Hz}), 164.6(\mathrm{dd}, J=12.7,258.5 \mathrm{~Hz}), 162.5(\mathrm{dd}, J=13.2,261.9 \mathrm{~Hz})$, 155.6, 155.5, 153.3, 150,6, 146.5 (q, $J=4.7 \mathrm{~Hz}), 137.2$ (q, $J=3.4 \mathrm{~Hz}), 129.6,127.1-126.6$ (m), 126.0, 125.4 (q, $J=34.6 \mathrm{~Hz}), 123.9$ (d, $J=20.9 \mathrm{~Hz}), 122.2(\mathrm{q}, J=271.7 \mathrm{~Hz}), 114.4$ (dd, $J=3.1,17.9 \mathrm{~Hz}), 99.2(\mathrm{t}, J=27.1 \mathrm{~Hz}), 20.5$. MALDI HRMS for $\mathrm{C}_{36} \mathrm{H}_{22} \mathrm{~N}_{4} \mathrm{~F}_{10}{ }^{193} \mathrm{Ir}[\mathrm{M}]^{+}$: found 893.1209, calcd 893.130. Elemental analysis: calcd (\%) for $\mathrm{C}_{36} \mathrm{H}_{22} \mathrm{~N}_{4} \mathrm{~F}_{16} \mathrm{PIr}$ (1037.77): C 41.67, H 2.14, N 5.40; found: C 41.55, H 2.29, N 5.21.

Iridium(III)

bis[2-(4'-cyano-2,6-difluoro-[1,1'-biphenyl]-3-yl)-5(trifluoromethyl)pyridinato-N, $\mathrm{C}^{2}$ ']-4,4'-dimetyl-2,2'-bipyridine hexafluorophosphate (G2): $\quad \mathrm{IrCl}_{3} \cdot 6 \mathrm{H}_{2} \mathrm{O} \quad(75 \quad \mathrm{mg}, \quad 0.25 \quad \mathrm{mmol}, \quad 1.0 \quad$ eq. $)$ and 2',6'-difluoro-3'-(5(trifluoromethyl)pyridin-2-yl)-[1,1'-biphenyl]-4-carbonitrile (2) (180 mg, $0.5 \mathrm{mmol}, 2$ eq.) were suspended in a mixture of 2-ethoxyethanol/water $(5 \mathrm{~mL}, 3 / 1)$. The mixture was heated and kept at $125{ }^{\circ} \mathrm{C}$ under stirring. After $24 \mathrm{~h}$, it was allowed to cool to room temperature and the solvent was removed under vacuo to give the intermediate $\left[\operatorname{Ir}\left(\mathrm{C}^{\wedge} \mathrm{N}\right)_{2} \mathrm{Cl}\right]_{2}$ dimer complex, which was directly engaged in the next step without further purification. The crude mixture of $\left[\operatorname{Ir}\left(\mathrm{C}^{\wedge} \mathrm{N}\right)_{2} \mathrm{Cl}\right]_{2}$ (1.0 equiv.) was dissolved in $5 \mathrm{~mL}$ of $\mathrm{CH}_{2} \mathrm{Cl}_{2}$ before addition of 4,4'dimethyl-2,2'-bipyridine (69 mg, $0.375 \mathrm{mmol}, 1.5$ equiv.) and $\mathrm{AgPF}_{6}(95 \mathrm{mg}, 0.375 \mathrm{mmol}$, 1.5 equiv.). The resulting solution was stirred at RT over 16 hours away from light. After concentration, the crude mixture was purified by silica column chromatography to afford the desired complex G2 (217 mg, 70\%). ${ }^{1} \mathrm{H}$ NMR (400 MHz, Acetone- $\left.d_{6}\right) \delta(\mathrm{ppm}) 8.81(\mathrm{~s}, 2 \mathrm{H})$, $8.69(\mathrm{dd}, J=2.6,8.8 \mathrm{~Hz}, 2 \mathrm{H}), 8.46(\mathrm{dd}, J=2.2,8.8 \mathrm{~Hz}, 2 \mathrm{H}), 8.22(\mathrm{~d}, J=5.7 \mathrm{~Hz}, 2 \mathrm{H}), 8.07$ $(\mathrm{d}, J=2.1 \mathrm{~Hz}, 2 \mathrm{H}), 7.93(\mathrm{~d}, J=8.3 \mathrm{~Hz}, 4 \mathrm{H}), 7.75(\mathrm{~d}, J=7.9 \mathrm{~Hz}, 4 \mathrm{H}), 7.63$ (d, $J=5.8 \mathrm{~Hz}$, $2 \mathrm{H}), 6.21(\mathrm{~d}, J=9.4 \mathrm{~Hz}, 2 \mathrm{H}), 2.65(\mathrm{~s}, 6 \mathrm{H}) .{ }^{19} \mathrm{~F}\left\{{ }^{1} \mathrm{H}\right\} \mathrm{NMR}\left(376 \mathrm{MHz}\right.$, Acetone- $\left.d_{6}\right) \delta(\mathrm{ppm})$ 63.5, -72.6 (d, $J=707.4 \mathrm{~Hz}),-109.1(\mathrm{~d}, J=11.7 \mathrm{~Hz}),-112.8(\mathrm{~d}, J=11.9 \mathrm{~Hz}) .{ }^{13} \mathrm{C}\left\{{ }^{1} \mathrm{H}\right\} \mathrm{NMR}$ $\left(100 \mathrm{MHz}\right.$, Acetone- $\left.d_{6}\right) \delta(\mathrm{ppm}) 167.7(\mathrm{~d}, J=7.2 \mathrm{~Hz}), 160.9(\mathrm{dd}, J=6.8,259.6 \mathrm{~Hz}), 158.8$ $(\mathrm{dd}, J=7.4,263.0 \mathrm{~Hz}), 155.6,155.2(\mathrm{~d}, J=7.4 \mathrm{~Hz}), 153.4,150.7,146.2(\mathrm{q}, J=4.6 \mathrm{~Hz})$, $137.4(\mathrm{~m}), 134.2,132.2,131.3,129.7,127.6$ (q, $J=5.5 \mathrm{~Hz}), 126.0,125.7$ (q, $J=34.6 \mathrm{~Hz})$, $124.3(\mathrm{~d}, J=22.1 \mathrm{~Hz}), 122.12(\mathrm{q}, J=271.8 \mathrm{~Hz}), 118.2,115.0(\mathrm{~d}, J=17.8 \mathrm{~Hz}), 112.0(\mathrm{~m})$, 
111.8, 20.5. MALDI HRMS for $\mathrm{C}_{50} \mathrm{H}_{28} \mathrm{~N}_{6} \mathrm{~F}_{10}{ }^{193} \operatorname{Ir}[\mathrm{M}]^{+}$: found 1095.1839, calcd 1095.187. Elemental analysis: calcd (\%) for $\mathrm{C}_{50} \mathrm{H}_{28} \mathrm{~N}_{6} \mathrm{~F}_{16} \mathrm{PIr}$ (1239.89): C 48.43, H 2.28, N 6.78; found: C 48.39, H 2.31, N 6.54.

Iridium(III) bis[2-((4'-(ethoxycarbonyl)-2,6-difluoro-[1,1'-biphenyl] 3-yl)-5(trifluoromethyl)pyridinato-N, $\mathrm{C}^{2}$ ']-4,4'-dimetyl-2,2'-bipyridine hexafluorophosphate (G3): $\quad \mathrm{IrCl}_{3} .6 \mathrm{H}_{2} \mathrm{O} \quad(75 \mathrm{mg}, \quad 0.25 \mathrm{mmol}, \quad 1.0$ eq. $)$ and ethyl 2',6'-difluoro-3'-(5(trifluoromethyl)pyridin-2-yl)-[1,1'-biphenyl]-4-carboxylate (3) (203 mg, 0.5 mmol, 2 eq.) were suspended in a mixture of 2-ethoxyethanol/water $(5 \mathrm{~mL}, 3 / 1)$. The mixture was heated and kept at $125^{\circ} \mathrm{C}$ under stirring. After $24 \mathrm{~h}$, it was allowed to cool to room temperature and the solvent was removed under vacuo to give the intermediate $\left[\operatorname{Ir}\left(\mathrm{C}^{\wedge} \mathrm{N}\right)_{2} \mathrm{Cl}\right]_{2}$ dimer complex, which was directly engaged in the next step without further purification. The crude mixture of $\left[\operatorname{Ir}\left(\mathrm{C}^{\wedge} \mathrm{N}\right)_{2} \mathrm{Cl}\right]_{2}$ (1.0 equiv.) was dissolved in $5 \mathrm{~mL}$ of $\mathrm{CH}_{2} \mathrm{Cl}_{2}$ before addition of 4,4'dimethyl-2,2'-bipyridine (69 mg, $0.375 \mathrm{mmol}, 1.5$ equiv.) and $\mathrm{AgPF}_{6}(95 \mathrm{mg}, 0.375 \mathrm{mmol}$, 1.5 equiv.). The resulting solution was stirred at RT over 16 hours away from light. After concentration, the crude mixture was purified by silica column chromatography to afford the desired complex G3 (226 mg, 68\%). ${ }^{1} \mathrm{H}$ NMR (400 MHz, $\left.\mathrm{CDCl}_{3}\right) \delta(\mathrm{ppm}) 8.67$ (s, 2H), 8.59 $-8.51(\mathrm{~m}, 2 \mathrm{H}), 8.11(\mathrm{dd}, J=8.3,13.2 \mathrm{~Hz}, 6 \mathrm{H}), 7.92(\mathrm{~d}, J=5.7 \mathrm{~Hz}, 2 \mathrm{H}), 7.66(\mathrm{~s}, 2 \mathrm{H}), 7.58$ $(\mathrm{d}, J=8.0 \mathrm{~Hz}, 4 \mathrm{H}), 7.48(\mathrm{~d}, J=5.7 \mathrm{~Hz}, 2 \mathrm{H}), 5.85(\mathrm{~d}, J=8.8 \mathrm{~Hz}, 2 \mathrm{H}), 4.41(\mathrm{q}, J=7.1 \mathrm{~Hz}$, $4 \mathrm{H}), 2.65(\mathrm{~s}, 6 \mathrm{H}), 1.42(\mathrm{t}, J=7.1 \mathrm{~Hz}, 6 \mathrm{H}) .{ }^{19} \mathrm{~F}\left\{{ }^{1} \mathrm{H}\right\} \mathrm{NMR}\left(376 \mathrm{MHz}, \mathrm{CDCl}_{3}\right) \delta(\mathrm{ppm})-62.8$, $72.6(\mathrm{~d}, J=712.5 \mathrm{~Hz}),-105.4(\mathrm{~d}, J=13.5 \mathrm{~Hz}),-110.5(\mathrm{~d}, J=14.2 \mathrm{~Hz}) .{ }^{13} \mathrm{C}\left\{{ }^{1} \mathrm{H}\right\} \mathrm{NMR}(100$ $\left.\mathrm{MHz}, \mathrm{CDCl}_{3}\right) \delta(\mathrm{ppm}) 168.0(\mathrm{~d}, J=7.1 \mathrm{~Hz}), 166.2,161.5(\mathrm{dd}, J=7.0,262.5 \mathrm{~Hz}), 159.2(\mathrm{dd}$, $J=7.0,264.4 \mathrm{~Hz}), 154.9,154.5,153.5$ (d, $J=7.4 \mathrm{~Hz}), 149.6,148.7,144.9$ (q, $J=5.0 \mathrm{~Hz})$, 136.7, 133.5, 130.3, 130.2, 130.0, 129.4, 126.8, 126.4 (q, $J=35.0 \mathrm{~Hz}), 124.1$ (d, $J=22.7$ $\mathrm{Hz}), 123.5(\mathrm{q}, J=272.1 \mathrm{~Hz}), 122.9,120.2,114.5(\mathrm{~d}, J=19.1 \mathrm{~Hz}), 113.3(\mathrm{t}, J=19.8 \mathrm{~Hz})$, 61.1, 29.7, 14.3. MALDI HRMS for $\mathrm{C}_{54} \mathrm{H}_{38} \mathrm{~N}_{4} \mathrm{O}_{4} \mathrm{~F}_{10}{ }^{193} \mathrm{Ir}[\mathrm{M}]^{+}$: found 1189.2357, calcd 1189.232. Elemental analysis: calcd (\%) for $\mathrm{C}_{54} \mathrm{H}_{38} \mathrm{~N}_{4} \mathrm{O}_{4} \mathrm{~F}_{16} \mathrm{PIr}$ (1334.09): C 48.62, H 2.87, N 4.20; found: C 48.69, H 2.61, N 4.42. 
(G4): $\mathrm{IrCl}_{3} \cdot 6 \mathrm{H}_{2} \mathrm{O} \quad(75 \mathrm{mg}, \quad 0.25 \mathrm{mmol}, 1.0$ eq. $)$ and ethyl 1-(2',6'-difluoro-3'-(5(trifluoromethyl)pyridin-2-yl)-[1,1'-biphenyl]-4-yl)ethan-1-one (4) (138 mg, $0.5 \mathrm{mmol}, 2$ eq.) were suspended in a mixture of 2-ethoxyethanol/water $(5 \mathrm{~mL}, 3 / 1)$. The mixture was heated and kept at $125^{\circ} \mathrm{C}$ under stirring. After $24 \mathrm{~h}$, it was allowed to cool to room temperature and the solvent was removed under vacuo to give the intermediate $\left[\operatorname{Ir}\left(\mathrm{C}^{\wedge} \mathrm{N}\right)_{2} \mathrm{Cl}\right]_{2}$ dimer complex, which was directly engaged in the next step without further purification. The crude mixture of $\left[\operatorname{Ir}\left(\mathrm{C}^{\wedge} \mathrm{N}\right)_{2} \mathrm{Cl}\right]_{2}$ (1.0 equiv.) was dissolved in $5 \mathrm{~mL}$ of $\mathrm{CH}_{2} \mathrm{Cl}_{2}$ before addition of 4,4'dimethyl-2,2'-bipyridine (69 mg, $0.375 \mathrm{mmol}, 1.5$ equiv.) and $\mathrm{AgPF}_{6}(95 \mathrm{mg}, 0.375 \mathrm{mmol}$, 1.5 equiv.). The resulting solution was stirred at RT over 16 hours away from light. After concentration, the crude mixture was purified by silica column chromatography to afford the desired complex G4 (204 mg, 64\%). ${ }^{1} \mathrm{H}$ NMR (400 MHz, Acetone- $\left.d_{6}\right) \delta(\mathrm{ppm}) 8.81(\mathrm{~s}, 2 \mathrm{H})$, $8.74-8.66(\mathrm{~m}, 2 \mathrm{H}), 8.48-8.41(\mathrm{~m}, 2 \mathrm{H}), 8.26-8.21(\mathrm{~m}, 2 \mathrm{H}), 8.12(\mathrm{~d}, J=8.2 \mathrm{~Hz}, 2 \mathrm{H}), 8.09$ - $8.06(\mathrm{~m}, 2 \mathrm{H}), 7.69-7.63(\mathrm{~m}, 4 \mathrm{H}), 7.60$ (d, J=8.2 Hz, 2H), 7.49 (d, J=8.2 Hz, 2H), $6.24-$ $6.11(\mathrm{~m}, 2 \mathrm{H}), 2.66(\mathrm{~s}, 6 \mathrm{H}), 2.65(\mathrm{~s}, 6 \mathrm{H}) .{ }^{19} \mathrm{~F}\left\{{ }^{1} \mathrm{H}\right\} \mathrm{NMR}\left(376 \mathrm{MHz}, \mathrm{CDCl}_{3}\right) \delta(\mathrm{ppm})-63.5$, $72.5(\mathrm{~d}, J=707.4 \mathrm{~Hz}),-108.7(\mathrm{~d}, J=12.2 \mathrm{~Hz}),-112.6(\mathrm{~d}, J=12.8 \mathrm{~Hz}) .{ }^{13} \mathrm{C}\left\{{ }^{1} \mathrm{H}\right\} \mathrm{NMR}(100$ $\left.\mathrm{MHz}, \mathrm{CDCl}_{3}\right) \delta(\mathrm{ppm}) 196.7,167.9(\mathrm{~d}, J=7.7 \mathrm{~Hz}), 161.1(\mathrm{dd}, J=6.7,259.2 \mathrm{~Hz}), 159.1(\mathrm{md}$, $J=237.7 \mathrm{~Hz}), 155.7,154.5(\mathrm{~d}, J=7.7 \mathrm{~Hz}), 153.3(\mathrm{q}, J=3.0 \mathrm{~Hz}), 150.7,150.6,146.2(\mathrm{~m})$, 137.3, 136.7, 133.9, 130.6, 129.7, 128.1, 128.4 (q, $J=35.9 \mathrm{~Hz}), 127.4(\mathrm{~m}), 126.0,125.2$, 124.2 (md, $J=22.5 \mathrm{~Hz}), 122.2$ (q, $J=271.7 \mathrm{~Hz}), 114.9$ (md, $J=16.6 \mathrm{~Hz}), 108.3,25.8,20.5$. MALDI HRMS for $\mathrm{C}_{52} \mathrm{H}_{34} \mathrm{~N}_{4} \mathrm{O}_{2} \mathrm{~F}_{10}{ }^{193} \mathrm{Ir}[\mathrm{M}]^{+}$: found 1129.2146, calcd 1129.218. Elemental analysis: calcd (\%) for $\mathrm{C}_{52} \mathrm{H}_{34} \mathrm{~N}_{4} \mathrm{O}_{2} \mathrm{~F}_{16} \mathrm{PIr}$ (1274.04): C 49.02, H 2.69, N 4.40; found: C 49.17, H 2.86, N 4.20.

Iridium(III) bis[2-(3,5-difluorophenyl)-5-(trifluoromethyl)pyridinato-N,C $\left.{ }^{2}\right]-4,4$ 'dimetyl-2,2'-bipyridine hexafluorophosphate (G5): $\mathrm{IrCl}_{3} \cdot 6 \mathrm{H}_{2} \mathrm{O}(75 \mathrm{mg}, 0.25 \mathrm{mmol}, 1.0$ equiv.) and 2-(3,5-difluorophenyl)-5-(trifluoromethyl)pyridine (5) (129 mg, 0.5 mmol, 2 eq.) were suspended in a mixture of 2-ethoxyethanol/water $(5 \mathrm{~mL}, 3 / 1)$. The mixture was heated and kept at $125^{\circ} \mathrm{C}$ under stirring. After $24 \mathrm{~h}$, it was allowed to cool to room temperature and the solvent was removed under vacuo to give the intermediate $\left[\operatorname{Ir}\left(\mathrm{C}^{\wedge} \mathrm{N}\right)_{2} \mathrm{Cl}\right]_{2}$ dimer complex, which was directly engaged in the next step without further purification. The crude mixture of $\left[\operatorname{Ir}\left(\mathrm{C}^{\wedge} \mathrm{N}\right)_{2} \mathrm{Cl}\right]_{2}$ (1.0 equiv.) was dissolved in $5 \mathrm{~mL}$ of $\mathrm{CH}_{2} \mathrm{Cl}_{2}$ before addition of 4,4'dimethyl-2,2'-bipyridine (69 mg, $0.375 \mathrm{mmol}, 1.5$ equiv.) and $\mathrm{AgPF}_{6}(95 \mathrm{mg}, 0.375 \mathrm{mmol}$, 
1.5 equiv.). The resulting solution was stirred at RT over 16 hours away from light. After concentration, the crude mixture was purified by silica column chromatography to afford the desired complex G5 (181 mg, 70\%). ${ }^{1} \mathrm{H}$ NMR (400 MHz, Acetone- $\left.d_{6}\right) \delta(\mathrm{ppm}) 8.79(\mathrm{~s}, 2 \mathrm{H})$, $8.57(\mathrm{~d}, J=8.6 \mathrm{~Hz}, 2 \mathrm{H}), 8.37(\mathrm{dd}, J=2.1,8.7 \mathrm{~Hz}, 2 \mathrm{H}), 8.14(\mathrm{~d}, J=5.7 \mathrm{~Hz}, 2 \mathrm{H}), 7.95-7.86$ $(\mathrm{m}, 4 \mathrm{H}), 7.65(\mathrm{~d}, J=5.6 \mathrm{~Hz}, 2 \mathrm{H}), 6.69(\mathrm{td}, J=2.4,9.4 \mathrm{~Hz}, 2 \mathrm{H}), 2.66(\mathrm{~s}, 6 \mathrm{H}) .{ }^{19} \mathrm{~F}\left\{{ }^{1} \mathrm{H}\right\} \mathrm{NMR}$ $\left(376 \mathrm{MHz}\right.$, Acetone- $\left.d_{6}\right) \delta(\mathrm{ppm})-63.4,-72.2(\mathrm{~d}, J=708.3 \mathrm{~Hz}),-102.5(\mathrm{~d}, J=7.6 \mathrm{~Hz}),-118.8$ $(\mathrm{d}, J=7.8 \mathrm{~Hz}) \cdot{ }^{13} \mathrm{C}\left\{{ }^{1} \mathrm{H}\right\}$ NMR $\left(100 \mathrm{MHz}\right.$, Acetone- $\left.d_{6}\right) \delta(\mathrm{ppm}) 170.7(\mathrm{~d}, J=4.6 \mathrm{~Hz}), 168.4$ $(\mathrm{dd}, J=11.2,238.9 \mathrm{~Hz}), 160.5(\mathrm{dd}, J=12.3,240.1 \mathrm{~Hz}), 155.9,153.4,150.3,146.7(\mathrm{dd}, J=$ 9.2, $17.6 \mathrm{~Hz}), 146.4(\mathrm{q}, J=4.9 \mathrm{~Hz}), 136.4(\mathrm{q}, J=3.4 \mathrm{~Hz}), 129.9,126.2,125.6$ (q, $J=34.3$ $\mathrm{Hz}), 124.7$ (dd, $J=3.0,36.4 \mathrm{~Hz}), 122.2(\mathrm{q}, J=271.8 \mathrm{~Hz}), 121.1,109.6(\mathrm{dd}, J=3.8,22.3 \mathrm{~Hz})$, $106.5\left(\mathrm{dd}, J=24.9,32.3 \mathrm{~Hz}\right.$ ), 20.5. MALDI HRMS for $\mathrm{C}_{36} \mathrm{H}_{22} \mathrm{~N}_{4} \mathrm{~F}_{10}{ }^{193} \operatorname{Ir}[\mathrm{M}]^{+}$: found 893.1209, calcd 893.130. Elemental analysis: calcd (\%) for $\mathrm{C}_{36} \mathrm{H}_{22} \mathrm{~N}_{4} \mathrm{~F}_{16} \mathrm{PIr}$ (1037.77): C 41.67, H 2.14, N 5.40; found: C 41.84, H 2.31, N 5.67.

Iridium(III)

bis[2-((4'-(ethoxycarbonyl)-3,5-difluoro-[1,1'-biphenyl]-3-yl)-5(trifluoromethyl)pyridinato-N, $\mathrm{C}^{2}$ ']-4,4'-dimetyl-2,2'-bipyridine hexafluorophosphate

(G6): $\mathrm{IrCl}_{3} \cdot 6 \mathrm{H}_{2} \mathrm{O} \quad(75 \mathrm{mg}, 0.25 \mathrm{mmol}, 1.0$ eq.) and ethyl 3',5'-difluoro-3'-(5(trifluoromethyl)pyridin-2-yl)-[1,1'-biphenyl]-4-carboxylate (6) (203 mg, $0.5 \mathrm{mmol}, 2$ eq.) were suspended in a mixture of 2-ethoxyethanol/water $(5 \mathrm{~mL}, 3 / 1)$. The mixture was heated and kept at $125^{\circ} \mathrm{C}$ under stirring. After $24 \mathrm{~h}$, it was allowed to cool to room temperature and the solvent was removed under vacuo to give the intermediate $\left[\operatorname{Ir}\left(\mathrm{C}^{\wedge} \mathrm{N}\right)_{2} \mathrm{Cl}\right]_{2}$ dimer complex, which was directly engaged in the next step without further purification. The crude mixture of $\left[\operatorname{Ir}\left(\mathrm{C}^{\wedge} \mathrm{N}\right)_{2} \mathrm{Cl}\right]_{2}$ (1.0 equiv.) was dissolved in $5 \mathrm{~mL}$ of $\mathrm{CH}_{2} \mathrm{Cl}_{2}$ before addition of 4,4'dimethyl-2,2'-bipyridine (69 mg, $0.375 \mathrm{mmol}, 1.5$ equiv.) and $\mathrm{AgPF}_{6}$ (95 mg, $0.375 \mathrm{mmol}$, 1.5 equiv.). The resulting solution was stirred at RT over 16 hours away from light. After concentration, the crude mixture was purified by silica column chromatography to afford the desired complex G6 (213 mg, 64\%). ${ }^{1} \mathrm{H}$ NMR (400 MHz, $\left.\mathrm{CD}_{2} \mathrm{Cl}_{2}\right) \delta(\mathrm{ppm}) 8.47(\mathrm{~s}, 2 \mathrm{H})$, $8.06(\mathrm{~d}, J=8.2 \mathrm{~Hz}, 8 \mathrm{H}), 8.02(\mathrm{~d}, J=5.6 \mathrm{~Hz}, 2 \mathrm{H}), 7.68-7.60(\mathrm{~m}, 4 \mathrm{H}), 7.46(\mathrm{~d}, J=7.2 \mathrm{~Hz}$, $6 \mathrm{H}), 4.38(\mathrm{q}, J=7.1 \mathrm{~Hz}, 4 \mathrm{H}), 2.71(\mathrm{~s}, 6 \mathrm{H}), 1.41(\mathrm{t}, J=7.1 \mathrm{~Hz}, 6 \mathrm{H}) .{ }^{19} \mathrm{~F}\left\{{ }^{1} \mathrm{H}\right\}$ NMR $(376$ $\left.\mathrm{MHz}, \mathrm{CD}_{2} \mathrm{Cl}_{2}\right) \delta(\mathrm{ppm})-63.3,-73.0(\mathrm{~d}, J=710.9 \mathrm{~Hz}),-106.4,-120.9 .{ }^{13} \mathrm{C}\left\{{ }^{1} \mathrm{H}\right\} \mathrm{NMR}(100$ $\left.\mathrm{MHz}, \mathrm{CD}_{2} \mathrm{Cl}_{2}\right) \delta(\mathrm{ppm}) 170.1,165.9,174.2(\mathrm{dd}, J=7.0,246.7), 157.6$ (dd, $\left.J=7.0,246.7\right)$, 155.1, 154.2, 149.9, $145.6(\mathrm{~d}, J=4.6 \mathrm{~Hz}), 136.0(\mathrm{q}, J=3.8 \mathrm{~Hz}), 133.7,130.4,130.3,130.1$ 129.1, 126.2, 120.5, $124.4(\mathrm{~d}, J=2.6 \mathrm{~Hz}), 124.0(\mathrm{~d}, J=3.5 \mathrm{~Hz}), 121.8(\mathrm{q}, J=274.1 \mathrm{~Hz})$, 
120.5, 109.7 (dd, $J=3.7,24.0 \mathrm{~Hz}$ ), 61.1, 21.4, 14.1. MALDI HRMS for $\mathrm{C}_{54} \mathrm{H}_{38} \mathrm{~N}_{4} \mathrm{O}_{4} \mathrm{~F}_{10}{ }^{193} \mathrm{Ir}$ $[\mathrm{M}]^{+}$: found 1189.2357, calcd 1189.239. Elemental analysis: calcd (\%) for $\mathrm{C}_{54} \mathrm{H}_{38} \mathrm{~N}_{4} \mathrm{O}_{4} \mathrm{~F}_{16} \mathrm{PIr}$ (1334.09): C 48.62, H 2.87, N 4.20; found: C 48.45, H 2.90, N 4.21.

\section{ASSOCIATED CONTENT}

Crystallographic information file for F2 (CCDC 1964093) (CIF)

Crystallographic information file for F5 (CCDC 1964103) (CIF)

Crystallographic information file for F6 (CCDC 1964108) (CIF)

Crystallographic information file for $\mathbf{G 3}$ (CCDC 1964137) (CIF)

Crystallographic information file for G5 (CCDC 1964149) (CIF)

Experimental details on cyclic voltammetry, X-ray; ${ }^{1} \mathrm{H},{ }^{19} \mathrm{~F}$ and ${ }^{13} \mathrm{C}$ NMR spectra, (PDF)

\section{Corresponding Author}

*yunchi@cityu.edu.hk,_*veronique.guerchais@univ-rennes1.fr; *henri.doucet@univrennes1.fr; *jean-francois.soule@univ-rennes1.fr

\section{ACKNOWLEDGMENT}

R.B. is grateful to "Université Mohamed Premier, Oujda, Morocco" for providing financial support. We thank CNRS (I.E.A. Hong Kong) and UR1 for providing financial support.

\section{REFERENCES}

1. (a) You, Y.; Park, S. Y., Phosphorescent Iridium(iii) Complexes: Toward High Phosphorescence Quantum Efficiency through Ligand Control. Dalton Trans. 2009, 12671282; (b) Chi, Y.; Chou, P.-T., Transition-Metal Phosphors with Cyclometalating Ligands: Fundamentals and Applications. Chem. Soc. Rev. 2010, 39, 638-655; (c) Zhao, Q.; Li, F.; Huang, C., Phosphorescent Chemosensors Based on Heavy-Metal Complexes. Chem. Soc. Rev. 2010, 39, 3007-3030; (d) You, Y.; Nam, W., Photofunctional Triplet Excited Ctates of Cyclometalated Ir(III) Complexes: Beyond Electroluminescence. Chem. Soc. Rev. 2012, 41, 7061-7084; (e) Archetypal Iridium(III) Compounds for Optoelectronic and Photonic Applications. Eli Zysman-Colman ed.; John Wiley \& Sons Ltd.: Chichester, 2017; (f) Chi, Y.; Chang, T.-K.; Ganesan, P.; Rajakannu, P., Emissive bis-Tridentate Ir(III) Metal Complexes: Tactics, Photophysics and Applications. Coord. Chem. Rev. 2017, 346, 91-100; (g) Haghighatbin, M. A.; Laird, S. E.; Hogan, C. F., Electrochemiluminescence of Cyclometalated Iridium (III) Complexes. Curr. Opin. Electrochem. 2018, 7, 216-223; (h) 
Chi, Y.; Wang, S. F.; Ganesan, P., Emissive Iridium(III) Complexes with PhosphorousContaining Ancillary. Chem. Rec. 2019, 19, 1644-1666; (i) Feng, Z.; Sun, Y.; Yang, X.; Zhou, G., Novel Emission Color-Tuning Strategies in Heteroleptic Phosphorescent Ir(III) and Pt(II) Complexes. Chem. Rec. 2019, 19, 1710-1728.

2. Duan, J. P.; Sun, P. P.; Cheng, C. H., New Iridium Complexes as Highly Efficient Orange-Red Emitters in Organic Light-Emitting Diodes. Adv. Mater. 2003, 15, 224-228.

3. (a) Highly Efficient OLEDs with Phosphorescent Materials. Yersin, Hartmut ed.; John Wiley \& Sons: Weinheim, 2008; (b) He, L.; Duan, L.; Qiao, J.; Wang, R.; Wei, P.; Wang, L.; Qiu, Y., Blue-Emitting Cationic Iridium Complexes with 2-(1H-Pyrazol-1-yl)pyridine as the Ancillary Ligand for Efficient Light-Emitting Electrochemical Cells. Adv. Funct. Mater. 2008, 18, 2123-2131; (c) Ulbricht, C.; Beyer, B.; Friebe, C.; Winter, A.; Schubert, U. S., Recent Developments in the Application of Phosphorescent Iridium(III) Complex Systems. Adv. Mater. 2009, 21, 4418-4441; (d) Costa, R. D.; Ortí, E.; Bolink, H. J.; Graber, S.; Schaffner, S.; Neuburger, M.; Housecroft, C. E.; Constable, E. C., Archetype Cationic Iridium Complexes and Their Use in Solid-State Light-Emitting Electrochemical Cells. $A d v$. Funct. Mater. 2009, 19, 3456-3463; (e) Yersin, H.; Rausch, A. F.; Czerwieniec, R.; Hofbeck, T.; Fischer, T., The Triplet State of Organo-Transition Metal Compounds. Triplet Harvesting and Singlet Harvesting for Efficient OLEDs. Coord. Chem. Rev. 2011, 255, 26222652; (f) Costa, R. D.; Ortí, E.; Bolink, H. J.; Monti, F.; Accorsi, G.; Armaroli, N., Luminescent Ionic Transition-Metal Complexes for Light-Emitting Electrochemical Cells. Angew. Chem. Int. Ed. 2012, 51, 8178-8211; (g) Gildea, L. F.; Williams, J. A. G., 3 - Iridium and Platinum Complexes for OLEDs. In Organic Light-Emitting Diodes (OLEDs), Buckley, A., Ed. Woodhead Publishing: 2013; pp 77-113; (h) Martir, D. R.; Momblona, C.; Pertegás, A.; Cordes, D. B.; Slawin, A. M. Z.; Bolink, H. J.; Zysman-Colman, E., Chiral Iridium(III) Complexes in Light-Emitting Electrochemical Cells: Exploring the Impact of Stereochemistry on the Photophysical Properties and Device Performances. ACS Appl. Mater. Interfaces 2016, 8, 33907-33915.

4. (a) Tamayo, A. B.; Garon, S.; Sajoto, T.; Djurovich, P. I.; Tsyba, I. M.; Bau, R.; Thompson, M. E., Cationic Bis-cyclometalated Iridium(III) Diimine Complexes and Their Use in Efficient Blue, Green, and Red Electroluminescent Devices. Inorg. Chem. 2005, 44, 8723-8732; (b) He, L.; Duan, L.; Qiao, J.; Dong, G.; Wang, L.; Qiu, Y., Highly Efficient Blue-Green and White Light-Emitting Electrochemical Cells Based on a Cationic Iridium Complex with a Bulky Side Group. Chem. Mater. 2010, 22, 3535-3542; (c) Kessler, F.; Costa, R. D.; Di Censo, D.; Scopelliti, R.; Ortí, E.; Bolink, H. J.; Meier, S.; Sarfert, W.; 
Grätzel, M.; Nazeeruddin, M. K.; Baranoff, E., Near-UV to Red-Emitting Charged bisCyclometallated Iridium(iii) Complexes for Light-Emitting Electrochemical Cells. Dalton Trans. 2012, 41, 180-191; (d) Skórka, Ł.; Filapek, M.; Zur, L.; Małecki, J. G.; Pisarski, W.; Olejnik, M.; Danikiewicz, W.; Krompiec, S., Highly Phosphorescent Cyclometalated Iridium(III) Complexes for Optoelectronic Applications: Fine Tuning of the Emission Wavelength through Ancillary Ligands. J. Phys. Chem. C 2016, 120, 7284-7294; (e) Chau, N.-Y.; Ho, P.-Y.; Ho, C.-L.; Ma, D.; Wong, W.-Y., Color-Tunable Thiazole-Based Iridium(III) Complexes: Synthesis, Characterization and their OLED Applications. $J$. Organomet. Chem. 2017, 829, 92-100; (f) Lai, P.-N.; Teets, T. S., Ancillary Ligand Effects on Red-Emitting Cyclometalated Iridium Complexes. Chem. Eur. J. 2019, 25, 6026-6037.

5. (a) Su, S.-J.; Chiba, T.; Takeda, T.; Kido, J., Pyridine-Containing Triphenylbenzene Derivatives with High Electron Mobility for Highly Efficient Phosphorescent OLEDs. Adv. Mater. 2008, 20, 2125-2130; (b) Sasabe, H.; Gonmori, E.; Chiba, T.; Li, Y.-J.; Tanaka, D.; Su, S.-J.; Takeda, T.; Pu, Y.-J.; Nakayama, K.-i.; Kido, J., Wide-Energy-Gap ElectronTransport Materials Containing 3,5-Dipyridylphenyl Moieties for an Ultra High Efficiency Blue Organic Light-Emitting Device. Chem. Mater. 2008, 20, 5951-5953; (c) Xiao, L.; Su, S.-J.; Agata, Y.; Lan, H.; Kido, J., Nearly 100\% Internal Quantum Efficiency in an Organic Blue-Light Electrophosphorescent Device Using a Weak Electron Transporting Material with a Wide Energy Gap. Adv. Mater. 2009, 21, 1271-1274; (d) Bin, J.-K.; Cho, N.-S.; Hong, J.I., New Host Material for High-Performance Blue Phosphorescent Organic Electroluminescent Devices. Adv. Mater. 2012, 24, 2911-2915; (e) Baranoff, E.; Curchod, B. F. E., FIrpic: Archetypal Blue Phosphorescent Emitter for Electroluminescence. Dalton Trans. 2015, 44, 8318-8329.

6. Lee, S.; Kim, S.-O.; Shin, H.; Yun, H.-J.; Yang, K.; Kwon, S.-K.; Kim, J.-J.; Kim, Y.-H., Deep-Blue Phosphorescence from Perfluoro Carbonyl-Substituted Iridium Complexes. J. Am. Chem. Soc. 2013, 135, 14321-14328.

7. Okamura, N.; Nakamura, T.; Yagi, S.; Maeda, T.; Nakazumi, H.; Fujiwara, H.; Koseki, S., Novel bis- and tris-Cyclometalated Iridium(iii) Complexes Bearing a Benzoyl Group on Each Fluorinated 2-Phenylpyridinate Ligand Aimed at Development of Blue Phosphorescent Materials for OLED. RSC Adv. 2016, 6, 51435-51445.

8. Yu, H.; Liu, C.; Lv, X.; Xiu, J.; Zhao, J., Effect of Substituents on Properties of Diphenylphosphoryl-Substituted bis-Cyclometalated Ir(III) Complexes with a Picolinic Acid as Ancillary Ligand. Dyes Pigm. 2017, 145, 136-143. 
9. Yun, S.-J.; Jeon, J.; Jin, S.-H.; Kang, S. K.; Kim, Y.-I., Synthesis, Structure, and OLEDs Application of Cyclometalated Iridium(III) Complexes Utilizing Substituted 2Phenylpyridine. Bull. Korean Chem. Soc. 2017, 38, 788-794.

10. (a) Kozhevnikov, V. N.; Zheng, Y.; Clough, M.; Al-Attar, H. A.; Griffiths, G. C.; Abdullah, K.; Raisys, S.; Jankus, V.; Bryce, M. R.; Monkman, A. P., Cyclometalated Ir(III) Complexes for High-Efficiency Solution-Processable Blue PhOLEDs. Chem. Mater. 2013, 25, 2352-2358; (b) Rota Martir, D.; Hedley, G. J.; Cordes, D. B.; Slawin, A. M. Z.; Escudero, D.; Jacquemin, D.; Kosikova, T.; Philp, D.; Dawson, D. M.; Ashbrook, S. E.; Samuel, I. D. W.; Zysman-Colman, E., Exploring the Self-Assembly and Energy Transfer of Dynamic Supramolecular Iridium-Porphyrin Systems. Dalton Trans. 2016, 45, 17195-17205; (c) Suhr, K. J.; Bastatas, L. D.; Shen, Y.; Mitchell, L. A.; Holliday, B. J.; Slinker, J. D., Enhanced Luminance of Electrochemical Cells with a Rationally Designed Ionic Iridium Complex and an Ionic Additive. ACS Appl. Mater. Interfaces 2016, 8, 8888-8892; (d) Rota Martir, D.; Bansal, A. K.; Di Mascio, V.; Cordes, D. B.; Henwood, A. F.; Slawin, A. M. Z.; Kamer, P. C. J.; Martínez-Sarti, L.; Pertegás, A.; Bolink, H. J.; Samuel, I. D. W.; Zysman-Colman, E., Enhancing the Photoluminescence Auantum Yields of Blue-Emitting Cationic Iridium(iii) Complexes Bearing Bisphosphine Ligands. Inorg. Chem. Front. 2016, 3, 218-235; (e) Hierlinger, C.; Trzop, E.; Toupet, L.; Ávila, J.; La-Placa, M.-G.; Bolink, H. J.; Guerchais, V.; Zysman-Colman, E., Impact of the Use of Sterically Congested Ir(iii) Complexes on the Performance of Light-Emitting Electrochemical Cells. J. Mater. Chem. C 2018, 6, 6385-6397.

11. Boyaala, R.; Touzani, R.; Roisnel, T.; Dorcet, V.; Caytan, E.; Jacquemin, D.; Boixel, J.; Guerchais, V.; Doucet, H.; Soulé, J.-F., Catalyst-Controlled Regiodivergent C-H Arylation Site of Fluorinated 2-Arylpyridine Derivatives: Application to Luminescent Iridium(III) Complexes. ACS Catal. 2019, 9, 1320-1328.

12. Bünzli, A. M.; Constable, E. C.; Housecroft, C. E.; Prescimone, A.; Zampese, J. A.; Longo, G.; Gil-Escrig, L.; Pertegás, A.; Ortí, E.; Bolink, H. J., Exceptionally Long-Lived Light-Emitting Electrochemical Cells: Multiple Intra-Cation $\pi$-Stacking Interactions in $\left[\operatorname{Ir}\left(\mathrm{C}^{\wedge} \mathrm{N}\right) 2\left(\mathrm{~N}^{\wedge} \mathrm{N}\right)\right][\mathrm{PF} 6]$ Emitters. Chem. Sci. 2015, 6, 2843-2852.

13. (a) Ackermann, L.; Vicente, R.; Kapdi, A. R., Transition-Metal-Catalyzed Direct Arylation of (Hetero)Arenes by $\mathrm{C}-\mathrm{H}$ Bond Cleavage. Angew. Chem. Int. Ed. 2009, 48, 97929826; (b) Chen, X.; Engle, K. M.; Wang, D.-H.; Yu, J.-Q., Palladium(II)-Catalyzed C-H Activation/C-C Cross-Coupling Reactions: Versatility and Practicality. Angew. Chem. Int. Ed. 2009, 48, 5094-5115; (c) Satoh, T.; Miura, M., Transition-Metal-Catalyzed 
Regioselective Arylation and Vinylation of Carboxylic Acids. Synthesis 2010, 3395-3409; (d) Hirano, K.; Miura, M., Recent Advances in Copper-mediated Direct Biaryl Coupling. Chem. Lett. 2015, 44, 878-873; (e) Sinha, S. K.; Zanoni, G.; Maiti, D., Natural Product Synthesis by C-H Activation. Asian J. Org. Chem. 2018, 7, 1178-1192; (f) Hagui, W.; Doucet, H.; Soulé, J.-F., Application of Palladium-Catalyzed C(sp2)-H Bond Arylation to the Synthesis of Polycyclic (Hetero)Aromatics. Chem 2019, 5, 2006-2078.

14. He, M.; Soulé, J.-F.; Doucet, H., Synthesis of (Poly)fluorobiphenyls through Metalcatalyzed C-H Bond Activation/Arylation of (Poly)fluorobenzene Derivatives. ChemCatChem 2014, 6, 1824-1859.

15. (a) Lafrance, M.; Rowley, C. N.; Woo, T. K.; Fagnou, K., Catalytic Intermolecular Direct Arylation of Perfluorobenzenes. J. Am. Chem. Soc. 2006, 128, 8754-8756; (b) GarciaCuadrado, D.; de Mendoza, P.; Braga, A. A. C.; Maseras, F.; Echavarren, A. M., ProtonAbstraction Mechanism in the Palladium-Catalyzed Intramolecular Arylation: Substituent Effects. J. Am. Chem. Soc. 2007, 129, 6880-6886; (c) Ackermann, L.; Fenner, S., Direct Arylations of Electron-Deficient (Hetero)arenes with Aryl or Alkenyl Tosylates and Mesylates. Chem. Commun. 2011, 47, 430-432; (d) Bernhammer, J. C.; Huynh, H. V., Pyrazolin-5-ylidene Palladium(II) Complexes: Synthesis, Characterization, and Application in the Direct Arylation of Pentafluorobenzene. Organometallics 2012, 31, 5121-5130; (e) He, M.; Soulé, J.-F.; Doucet, H., Reactivity of Para-Substituted Fluorobenzenes in Palladiumcatalyzed Intermolecular Direct Arylations. ChemCatChem 2015, 7, 2130-2140; (f) Obligacion, J. V.; Bezdek, M. J.; Chirik, P. J., C(sp2)-H Borylation of Fluorinated Arenes Using an Air-Stable Cobalt Precatalyst: Electronically Enhanced Site Selectivity Enables Synthetic Opportunities. J. Am. Chem. Soc. 2017, 139, 2825-2832.

16. Wang, Y.-N.; Guo, X.-Q.; Zhu, X.-H.; Zhong, R.; Cai, L.-H.; Hou, X.-F., $\mathrm{Pd}(\mathrm{OAc}) 2-\mathrm{Catalyzed}$ Direct Arylation of Electron-Deficient Arenes Without Ligands or With Monoprotected Amino Acid Assistance. Chem. Commun. 2012, 48, 10437-10439.

17. Lowry, M. S.; Goldsmith, J. I.; Slinker, J. D.; Rohl, R.; Pascal, R. A.; Malliaras, G. G.; Bernhard, S., Single-Layer Electroluminescent Devices and Photoinduced Hydrogen Production from an Ionic Iridium(III) Complex. Chem. Mater. 2005, 17, 5712-5719.

18. Leung, C. F.; Cheng, S. C.; Yang, Y.; Xiang, J.; Yiu, S. M.; Ko, C. C.; Lau, T. C., Efficient Photocatalytic Water Reduction by a Cobalt(II) Tripodal Iminopyridine Complex. Catal. Sci. Technol. 2018, 8, 307-313. 
19. Hsu, L.-Y.; Chen, D.-G.; Liu, S.-H.; Chiu, T.-Y.; Chang, C.-H.; Jen, A. K. Y.; Chou, P.-T.; Chi, Y., Roles of Ancillary Chelates and Overall Charges of Bis-tridentate Ir(III) Phosphors for OLED Applications. ACS Appl. Mater. Interfaces 2020, 12, 1084-1093.

20. Cantat, T.; Génin, E.; Giroud, C.; Meyer, G.; Jutand, A., Structural and kinetic effects of chloride ions in the palladium-catalyzed allylic substitutions. J. Organomet. Chem. 2003, 687, 365-376.

21. Luo, J.; Zhang, J., Donor-Acceptor Fluorophores for Visible-Light-Promoted Organic Synthesis: Photoredox/Ni Dual Catalytic C(sp3)-C(sp2) Cross-Coupling. ACS Catal. 2016, 6, 873-877. 